\title{
Petrogenesis of Archean PGM-bearing chromitites and associated ultramafic-mafic-anorthositic rocks from the Guelb el Azib layered complex (West African craton, Mauritania)
}

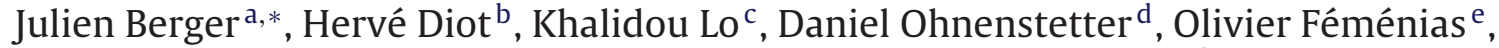 \\ Marjorie Pivin $^{a}$, Daniel Demaiffe ${ }^{a}$, Alain Bernard ${ }^{a}$, Bernard Charlier ${ }^{f}$ \\ a Département des Sciences de la Terre et de l'Environnement E' FRS-FNRS, Université Libre de Bruxelles, Belgium \\ b UMR CNRS 6112 "Laboratoire de Planétologie et de Géodynamique de Nantes", Université de Nantes, France \\ c Université de Nouakchott, Mauritania \\ d Centre de Recherches Pétrographiques et Géochimiques, CNRS, F-54501 Vandoeuvre lès Nancy, France \\ e IAMGOLD Corporation - West Africa, Mali \\ ${ }^{\mathrm{f}}$ Department of Earth, Atmospheric and Planetary Sciences, Massachusetts Institute of Technology, USA
}

\section{A R T I C L E I N F O}

\section{Article history:}

Received 7 March 2012

Received in revised form 4 October 2012

Accepted 8 October 2012

Available online xxx

\section{Keywords:}

Anorthosite

Layered complex

Archean tholeiite

Granulites

Mafic-ultramafic rocks

\begin{abstract}
A B S T R A C T
The Archean Guelb el Azib layered complex (GAC) in the West African craton of Mauritania is composed of an association of serpentinites, chromitites, amphibolites and anorthosites with few fine-grained amphibolite dykes. The complex forms tectonic slices in 2.9-3.5 Ga TTG gneiss terrains in close association with supracrustal rocks (BIFs, impure marbles, amphibolites). It was affected by a main granulite-facies grade metamorphism (up to $900^{\circ} \mathrm{C}$ at 5-6 kbar) with subsequent retrogression in amphibolite and greenschist facies conditions.

The preserved igneous macrostructures, the mineral compositions and the nature of relic magmatic assemblages have been used to constrain the composition of the parental melts and the conditions of crystallization. According to petrological observations and to comparison with experimental data, the formation of the complex can be explained by fractionation of a slightly hydrous high-alumina basaltic melt at low pressure. The early fractionation of olivine and the absence of massive clinopyroxene fractionation before plagioclase saturation led to crystallization of highly calcic plagioclase with Fe-, Al-rich but $\mathrm{Cr}$-poor chromite from a hydrous tholeiitic parental magma, similar to worldwide Archean tholeiites. The complex shares many similarities with Archean anorthosite layered complexes, possibly formed in a supra-subduction zone environment according to results obtained on similar 2.9-3.0 Ga complexes from Greenland and India (namely Fiskenaesset and Sittampundi). Three phases of PGE mineralization affected the GAC chromitites: (i) igneous crystallization of laurite; (ii) formation of late magmatic IPGE sulpho-arsenides (irarsite-hollingworthite) and (iii) hydrothermal Pt-Pd mineralization represented by sperrylite and rustenburgite.
\end{abstract}

(C) 2012 Elsevier B.V. All rights reserved.

\section{Introduction}

The association of highly calcic anorthosite and Fe-rich chromitite in ultramafic-mafic layered intrusions is almost exclusively restricted to Archean terrains (Windley et al., 1981; Ashwal, 1993; Rollinson et al., 2002, 2010; Dutta et al., 2011). These ultramafic-mafic-anorthosite (hereafter UMA) layered complexes are systematically closely associated with supracrustal rocks in strongly metamorphosed and deformed TTG terrains. They have

\footnotetext{
* Corresponding author. Present address: ETH Zurich, NO E 59, Sonneggstrasse, 5 8092 Zurich, Switzerland. Tel.: +41 4463281 67; fax: +41 446321030.

E-mail address: julien.berger@erdw.ethz.ch (J. Berger).
}

been recognized and well studied in the North Atlantic craton (the 2.97 Ga Fiskenaesset complex and 2.98 Naajat Kuuat complex in Greenland; Myers, 1976; Windley and Garde, 2009; Polat et al., 2010; Rollinson et al., 2010; Hoffmann et al., 2012), in the Indian Darhwar craton (the $2.9 \mathrm{Ga}$ Sittampundi and related complexes; Dutta et al., 2011; Dharma Rao et al., in press and references therein), in the Limpopo belt linking the Zimbabwe and Kaapvaal cratons (the $3.3 \mathrm{Ga}$ Messina layered intrusion; Hor et al., 1975; Barton, 1996; Mouri et al., 2009). Archean anorthosite-chromitite complexes in the Australian Pilbara craton have also probably similar origins (Hoatson and Sun, 2002). According to petrological, geochemical and isotopic studies of the Fiskenaesset and Sittampundi complexes, UMA are thought to represent the plutonic section of oceanic arc crust formed above subducting slabs 

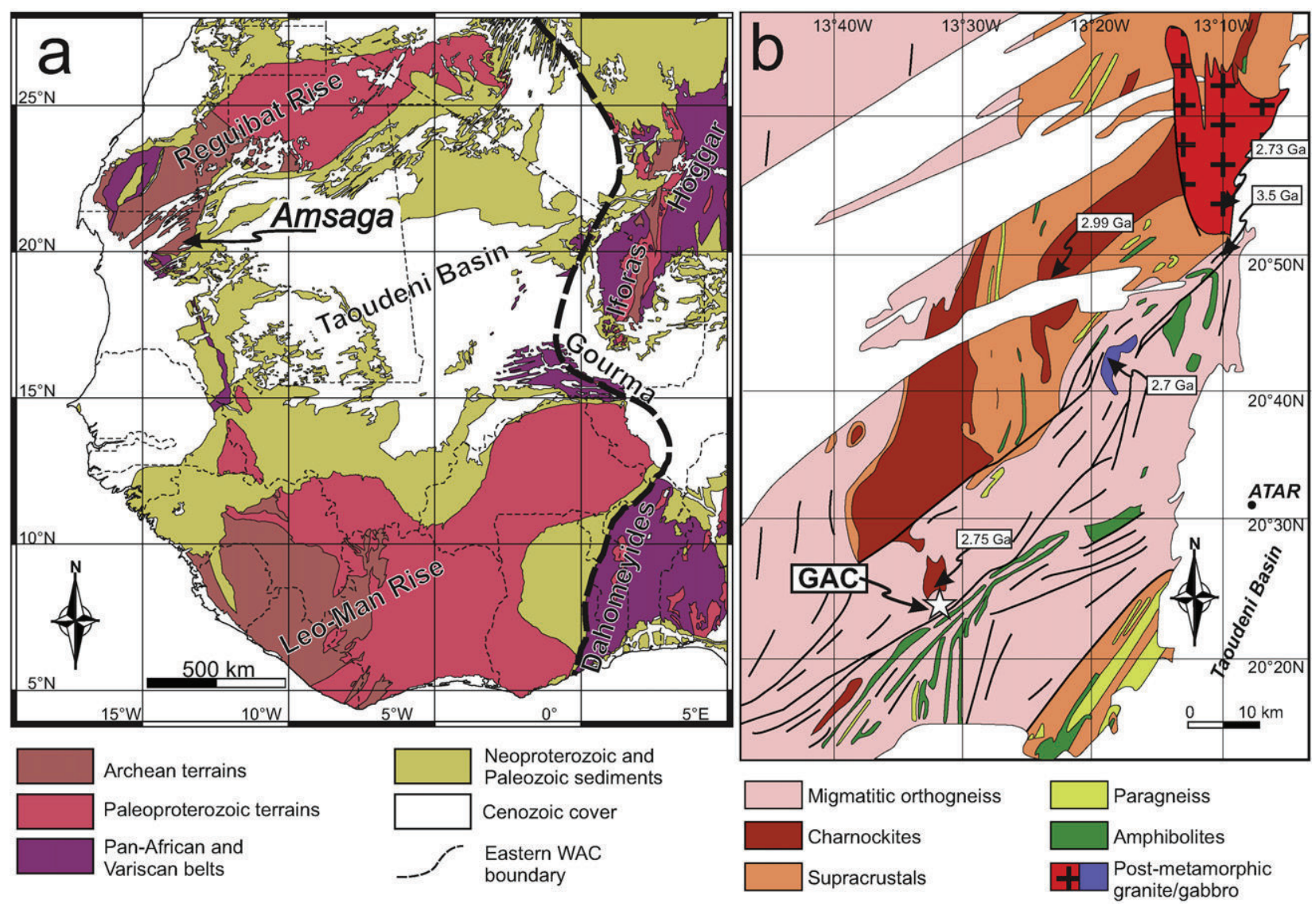

Fig. 1. Geological maps of the West African craton (a) and the Amsaga Area (b). The map of the Amsaga and the geochronological informations are from Potrel et al. (1998). GAC: Guelb el Azib Complex.

(Polat et al., 2009, 2010; Windley and Garde, 2009; Rollinson et al., 2010; Dutta et al., 2011; Hoffmann et al., 2012). Their close association with TTG (tectonic or intrusive relationships), interpreted as slab melts (Martin et al., 2005) or as partial melts from the base of thickened arc crust (Hoffmann et al., 2011), also argues in favour of a supra-subduction zone origin.

Hence, these UMA associations are markers to understand Archean arc magmatism and crustal recycling processes at subduction zones, and to characterize fluxes between mantle and island arc crust in the light of early oceanic and continental crustal growth. Disagreements persist about the geochemical nature of the primitive melt and its evolution with differentiation (tholeiitic aluminous basalt, Mg- and Al-rich ultrabasic magma; Weaver et al., 1981; Ashwal, 1993; Rollinson et al., 2010; Polat et al., 2011), the origin of highly calcic plagioclase and the occurrence of metamorphic versus igneous plagioclase-chromite-amphibole associations.

In this study, we present new data on the Archean Guelb el Azib complex, a new occurrence of layered anorthosite complex located in the West African craton of Mauritania. It is composed of a suite of ultramafic cumulates, chromitites, layered gabbros, leucogabbros and anorthosites metamorphosed under amphibolite and granulite grades. The primitive melt composition and its liquid line of descent are estimated in order to explain the relation between the different rock-types, the origin of high-Ca anorthosites and their association with Fe-rich chromitites. The degree and effect of high-grade metamorphism on the original igneous mineralogy of the complex and the link between PGE mineralization and chromitites are also discussed. Finally, we emphasize the importance of such complexes for a better understanding of Archean intra-oceanic subduction zone magmatism.

\section{Regional geology}

The West African Craton (WAC) comprises two large shields where Archean and Paleoproterozoic terrains crop out at the southern and northern borders of the Neoproterozoic and Mesozoic Taoudeni basin: the Leo-Man rise in the south (Ivory Coast, Guinea...) and the Reguibat rise in the northwestern Africa, within the Sahara desert (Fig. 1a).

The Amsaga area (Fig. 1b) (Barrère, 1967), located within the Reguibat rise, belongs to the Choum-Rag el Abiod terrane (Key et al., 2008) which is characterized by major magmatic events at $3.5,2.99,2.8$ and $2.7 \mathrm{Ga}$ with a main tectono-metamorphic event bracketed between 2.95 and 2.73 Ga (Auvray et al., 1992; Potrel, 1994; Potrel et al., 1996, 1998; Key et al., 2008). The northern part of the Amsaga area (Fig. 1b) is composed of supracrustal metasediments (metaquartzites, metagreywackes and metapelites) intruded by 2.99 Ga metamorphosed charnockitic plutons (Potrel, 1994; Potrel et al., 1998). The southern domain (Fig. 1b) is dominated by migmatitic, locally garnet-bearing, quartzo-feldspathic gneisses of TTG affinity with layers, sheets or lenses of amphibolite (former mafic dykes or lavas), banded iron formation (BIF), cipolin and chromitite/anorthositebearing mafic-ultramafic layered complexes dissected by Neoarchean shear zones. Post-metamorphic/late-kinematic formations (Fig. 1b) include the $2.73 \mathrm{Ga}$ Touijenjert-Modreïgue granite and the $2.7 \mathrm{Ga}$ Iguilid mafic intrusion (Potrel et al., 1998).

Except for volumetrically minor Paleoproterozoic to Jurassic mafic dykes, the Amsaga area underwent no major magmatic and/or metamorphic events since $2.7 \mathrm{Ga}$. The formation and 


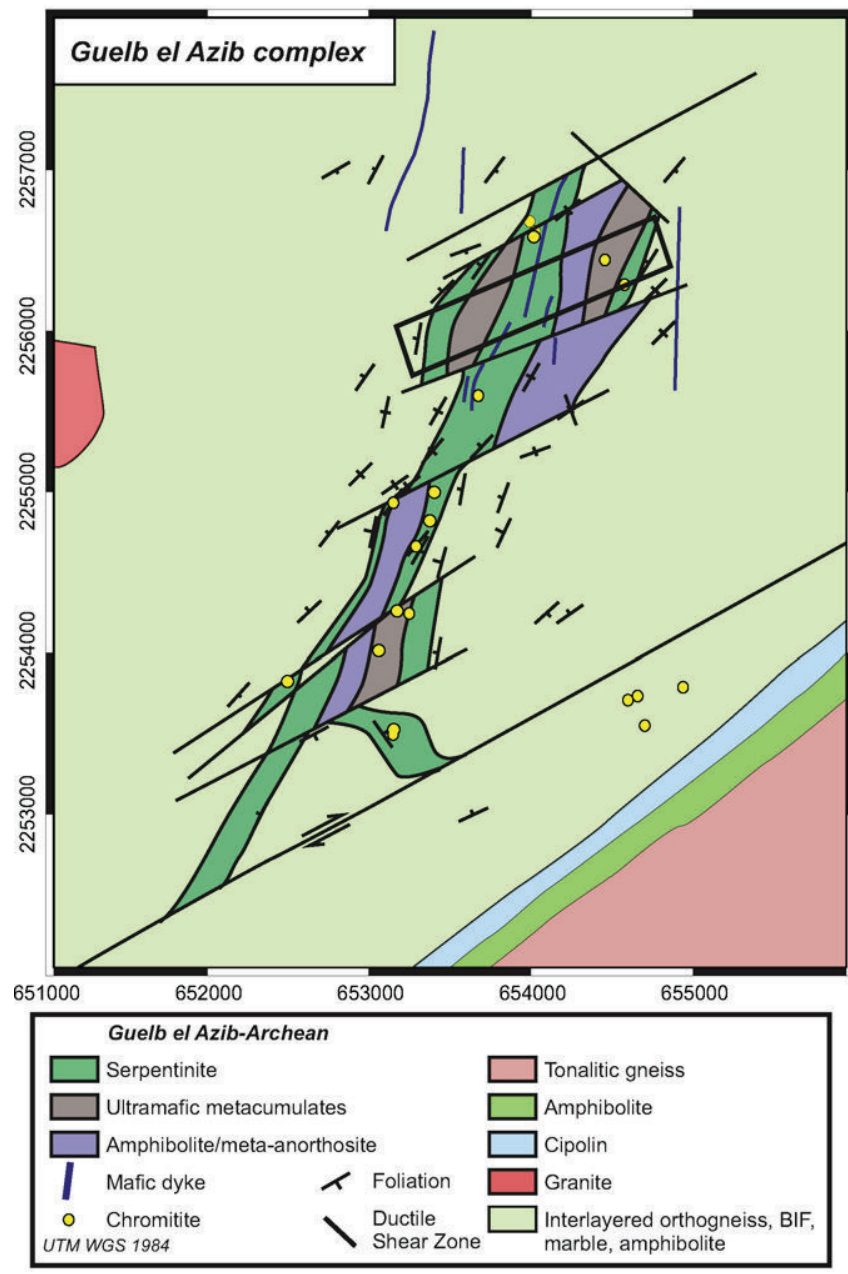

Fig. 2. Detailed geological map of the Guelb el Azib complex with the location of chromitite outcrops in the area. The rectangle refers to bloc diagram of Fig. 3.

reworking of the Mauritanides, a mixed Pan-African and Variscan orogenic belt, has led to thrusting of tectonic sheets onto the Archean rocks in the southwestern part of the Reguibat rise, but has not affected the studied area.

\section{Chromitites in the Amsaga area and the Guelb el Azib complex (GAC)}

Our fieldwork together with the observation of Barrère (1967) has revealed seven main occurrences of chromitites aligned along a NE-SW strike. Chromitites are associated with serpentinites, ultramafic meta-cumulates, mafic rocks (coarse-grained and finegrained amphibolites) and anorthosites. The whole association forms complexes dissected by late Archean N35 $-45^{\circ}$ dextral shear zones (Fig. 1b).

The largest complex (300-1500 m wide and $10 \mathrm{~km}$ long) located about $5 \mathrm{~km}$ south of Guelb el Azib (Figs. 1b and 2) is surrounded by porphyroclastic granodioritic and tonalitic orthogneisses, amphibolites and impure marbles (Fig. 2). BIFs lodes have only been observed on the eastern side of the complex, whereas few leucocratic garnet-sillimanite mylonitic orthogneisses occur exclusively on its western side (Figs. 2 and 3). Most foliations are upright with down-dip stretching lineations; some foliation planes are however only gently dipping away from the major shear zone. Late dextral strike-slip movements are evidenced by horizontal lineations and asymmetric mantled porphyroclasts in shear zones of several tens of kilometres length. This last ductile event is also attested by upright folds with vertical axis that are well expressed in the surrounding BIFs (Fig. 3).

The GAC is an allochthonous, highly tectonized, layered body affected by high- and low-grade metamorphism. Its original igneous stratigraphy can therefore not be reconstructed. The geometries of boundaries between the different lithological units presented on the geological map (Fig. 2) are simplified; they more closely correspond to those drawn on the block diagram of Fig. 3.

Chromitites crop out as lenses of several metres width and tens of metre length (Fig. 3). They often occur within serpentinites and metawebsterites. Chromitites are either massive, brecciated (Fig. 4b) or disseminated within the host cumulates. Some layered chromite pods have also been observed within anorthosite and leuco-amphibolite layers (Fig. 4c and sample MA 435), a common feature of Archean ultramafic-mafic-anorthosite complexes (Rollinson et al., 2010).

Serpentinites are deeply silicified, carbonated and oxidized (Fig. 4d). Consequently, neither high temperature anhydrous minerals (olivine, pyroxenes...) nor primary magmatic textures or structures are preserved. Spinel veins (Fig. 4d) and rodingitic dykes (hydrogrossular-prehnite-chlorite rocks) cut across the serpentinites. Talc is often present either as small patches or as

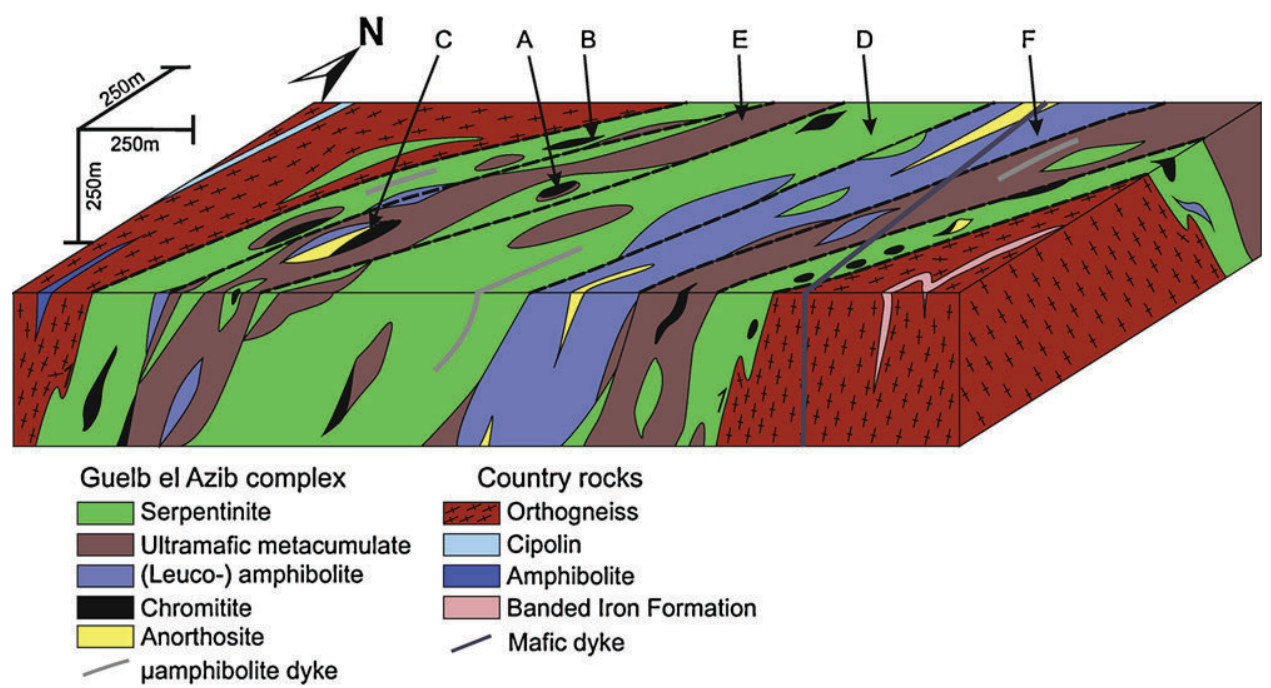

Fig. 3. Interpretative bloc diagram of the Guelb el Azib complex. The letters refer to field photographs in Fig. 4. The location of the cross section is shown in Fig. 2. 

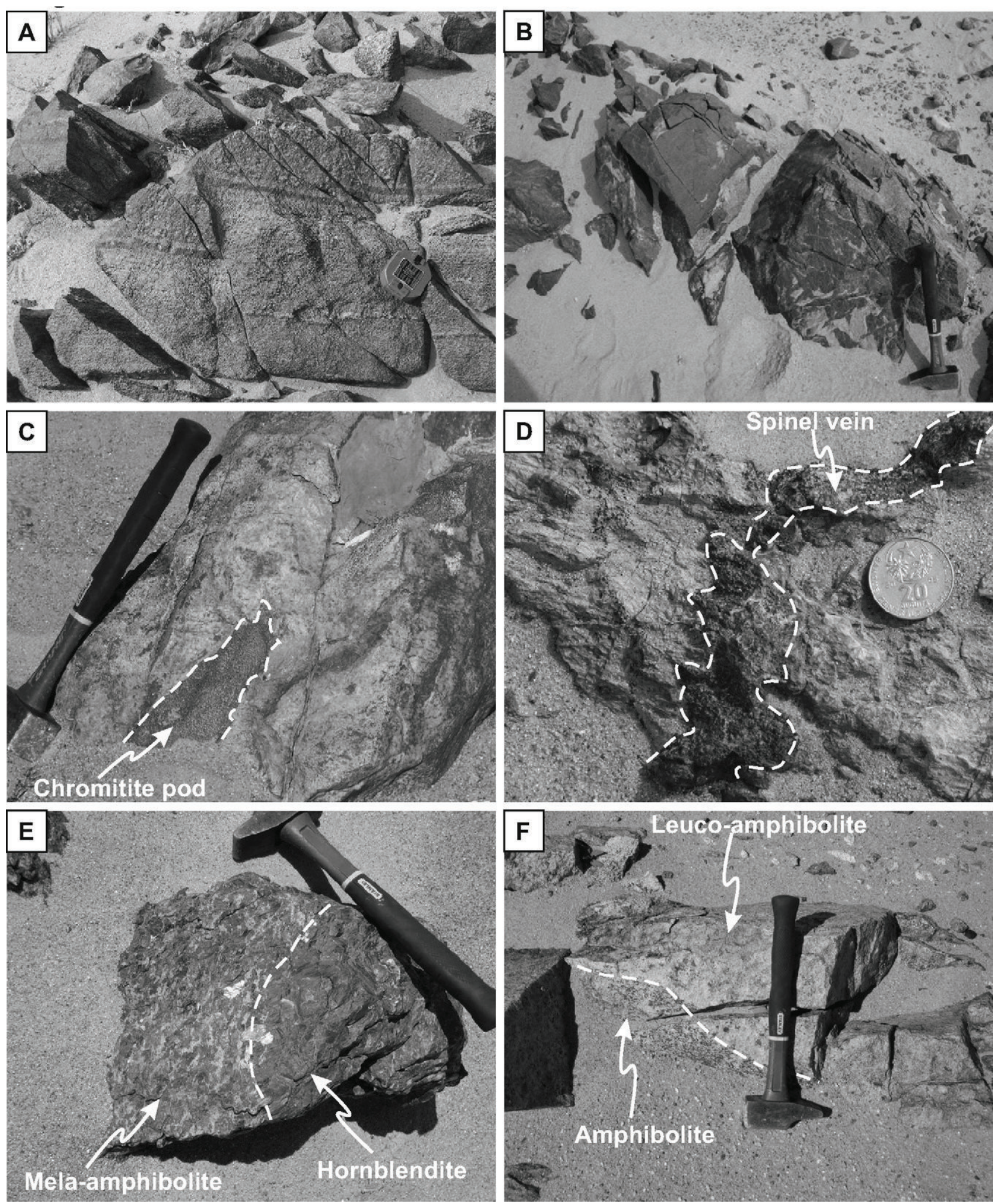

Fig. 4. Field photographs of rocks forming the Guelb el Azib complex: (A) layered chromitite; (B) brecciated and retrogressed chlorite chromitite; (C) chromitite pod in a leuco-amphibolite/anorthosite block; (D) spinel vein in carbonated and oxidized serpentinite; (E) layered hornblendite/mela-amphibolite; (F) layered leuco-amphibolite.

individualized spinel-talc rocks. Elliptical bodies of metawebsterite, hornblendite, amphibolite, anorthosite and chromitite are scattered within the main mass of serpentinite (Fig. 3).

The ultramafic cumulates consist of partly serpentinized metawebsterites, metatroctolites, hornblendite and mela-amphibolite, with some lenses of chromitites. Elliptical bodies of mafic material and serpentinite are also commonly found (Fig. 3). Despite strong deformation and pervasive metamorphism, igneous layering is preserved in both mela-amphibolites (Fig. 4e), ultramafic cumulates and a few chromitites. 
Table 1

Modal and textural properties of chromitite samples.

\begin{tabular}{|c|c|c|c|c|c|}
\hline Sample & $X$ & $Y$ & Texture & \% Chromite & Matrix mineral \\
\hline MA 17 & 643,562 & $2,242,634$ & Massive & 95 & Chlorite \\
\hline MA 44 & 653,300 & $2,254,645$ & Disseminated & 42 & Chlorite-calcite \\
\hline MA 226 & 657,930 & $2,274,050$ & Massive & 78 & Chlorite \\
\hline MA 238 & 654,701 & $2,253,581$ & Massive & 61 & Chlorite \\
\hline MA 239 & 654,656 & $2,253,739$ & Brecciated & 87 & Chlorite \\
\hline MA 273 & 653,400 & $2,255,000$ & Massive & 61 & Amphibole \\
\hline MA 400 & 654,028 & $2,256,615$ & Massive & 87 & Chlorite \\
\hline MA 420 & 653,144 & $2,253,504$ & Massive & 59 & Amphibole \\
\hline MA 422 & 652,474 & $2,253,808$ & Disseminated & 21 & Srp-Talc \\
\hline MA 425 & 653,050 & $2,254,000$ & Layered & $80-40$ & Amphibole \\
\hline MA 436 & 653,165 & $2,254,250$ & Brecciated & 65 & Chlorite \\
\hline MA 440 & 653,372 & $2,254,820$ & Massive & 69 & Amphibole \\
\hline
\end{tabular}

$X-Y$ : UTM coordinates ( $\mathrm{m})$, zone 28 , datum WGS 84 .

Anorthosites, leuco-amphibolites and meso-amphibolites form a distinct unit despite the presence of a few bodies of serpentinite. Igneous layering can still be found (Fig. 4f) but both metamorphism and ductile deformation affected the amphibolite. Scarce chromitite pods are interlayered within anorthosites/leuco-amphibolite.

Two generations of basic dykes are found within the GAC (Fig. 3): the oldest one of Archean age is affected by HT metamorphism and deformation, while the youngest one cuts across Archean structures and is oblique to foliation.

\section{Petrographic description}

\subsection{Chromitites}

Chromitites have been subdivided according to the modal proportion of spinels and the nature of the matrix silicate phase (Table 1).

Massive chromitites contain more than 50 vol.\% spinels (Fig. 5a-c). The main host silicate is pale greenish chlorite (MA 17, $226,238,400$ ) or green hornblende (MA 273, 420, 440). Chromite grains are angular and coarse (up to $5 \mathrm{~mm}$ ) in the chlorite-bearing samples (Fig. 5c), while they are small $(<1 \mathrm{~mm})$ and rounded in the amphibolite (Fig. 5a and b). Ferritchromit generally forms a thin rim around primary spinel or around chlorite and amphibole inclusions (Fig. 5b). Other silicate and oxide inclusions are scarce; they consist of nearly pure anorthite, magnesian olivine and rutile. Small shuiskite, Cr-pumpellyite and $\mathrm{Cr}$-grossular have been found, respectively, in the matrix and as inclusions in chromite from sample MA 440. Minute $(<7 \mu \mathrm{m})$ sulphide and arsenide inclusions are common, the dominant species being euhedral millerite (NiS), which is frequently found in close association with anorthite and rutile inclusions (Fig. 4d). The primary sulphides frequently display exsolution or replacement bands of pyrite and pentlandite. Covelite (CuS), chalcopyrite $\left(\mathrm{CuFeS}_{2}\right)$ and a single isolated gersdorffite (NiAsS) were also found within chromite grains.

Brecciated chromitites owe their aspect to the development of a network of chlorite-filled fractures. The host matrix mineral is chlorite and spinel with a spongy texture characterized by numerous inclusions of chlorite (Fig. 5c). The ferritchromit rim is largely developed; it can entirely invade some chromite, surround chlorite inclusion and outline fractures. Anhydrous silicate, oxide and sulphide inclusions have not been observed.

The only sample of layered chromitite (MA 425) selected for detailed investigation is in close association with anorthosite and leucogabbro. Despite its layered structure, this sample has exactly the same petrographical features as amphibole-bearing massive chromitites, except for a larger mean grain size (up to $5 \mathrm{~mm}$ wide) in the silicate-rich band.

Disseminated chromitites contain less than 50 vol.\% spinels; their matrix is either composed of serpentine with talc (MA 422) or chlorite with calcite (MA 44). Chromite grains are characterized by a thick ferritchromit rim, a frequent spongy texture due to numerous mineral inclusions (same nature as in the matrix), and the lack of anhydrous silicate, oxide and sulphide inclusions (Fig. 5e).

\subsection{Ultramafic metacumulates}

Four subgroups have been distinguished on the basis of the lithological nature of the sample: olivine-amphibole rocks, spinelamphibolite, mela-amphibolite and hornblendite (Table 2).

Olivine-amphibole rocks (Fig. 6a) are composed of olivine, spinel and amphibole. They are deeply serpentinized (more than 60 vol.\% of olivine were serpentinized), but the presence of rounded olivine relics surrounded by amphibole crystals, probably pseudomorphs after former pyroxenes, allows us to identify a former poikilitic texture. Green spinel is surrounded or totally replaced by magnetite.

Spinel-amphibolites (Fig. 6b) show the association spinel-amphibole-anorthite (MA 264) or spinel-amphibole-olivine-orthopyroxene (MA 25). These samples are affected by a strong deformation outlined by large elongated amphibole prisms (up to $1 \mathrm{~cm}$ ). Granular polyhedral amphibole neoblasts crystallized at the borders of larger porphyroclasts indicate a high-temperature recrystallization process. Plagioclase grains are polyhedral and do not show evidence of internal strain. They are, however, partly altered into albite-epidote intergrowths. Green spinel and olivine $(<2 \mathrm{~mm})$ are interstitial to amphibole porphyroclasts.

\subsection{Amphibolites and anorthosites}

Mela-amphibolites (Fig. 6c) consist of brown amphibole + plagioclase \pm ilmenite \pm clinopyroxene \pm orthopyroxene. Two types of textures have been observed: (i) undeformed polyhedral plagioclase grains with large prismatic amphibole (MA 262 and 401), (ii) undulatory plagioclase with deformation twins and small granular amphibole representing the recrystallization product of larger prophyroclasts (MA 28 and 34). Former anhydrous granulitic assemblages and granular textures are still observed in a few samples (ex: MA 401). Brown amphibole grows at the expense of clinopyroxene grains (Fig. 6c) indicating that amphibole is not a primary igneous phase. Plagioclase is partly altered into association of epidote, albite and sulphides.

One sample of hornblendite (MA 258) has been selected; it is exclusively composed of large (up to $5 \mathrm{~cm}$ long) oriented prismatic brown amphibole (Fig. 4e).

The anorthosite MA 424 (Fig. 6d) is exclusively composed of plagioclase (with a mean size of $3 \mathrm{~mm}$ ) which displays lobate boundaries, internal strain evidenced by undulose extinction and deformation twins. The rock has been affected by both high-temperature grain-boundary-migration (GBM) and subgrain 

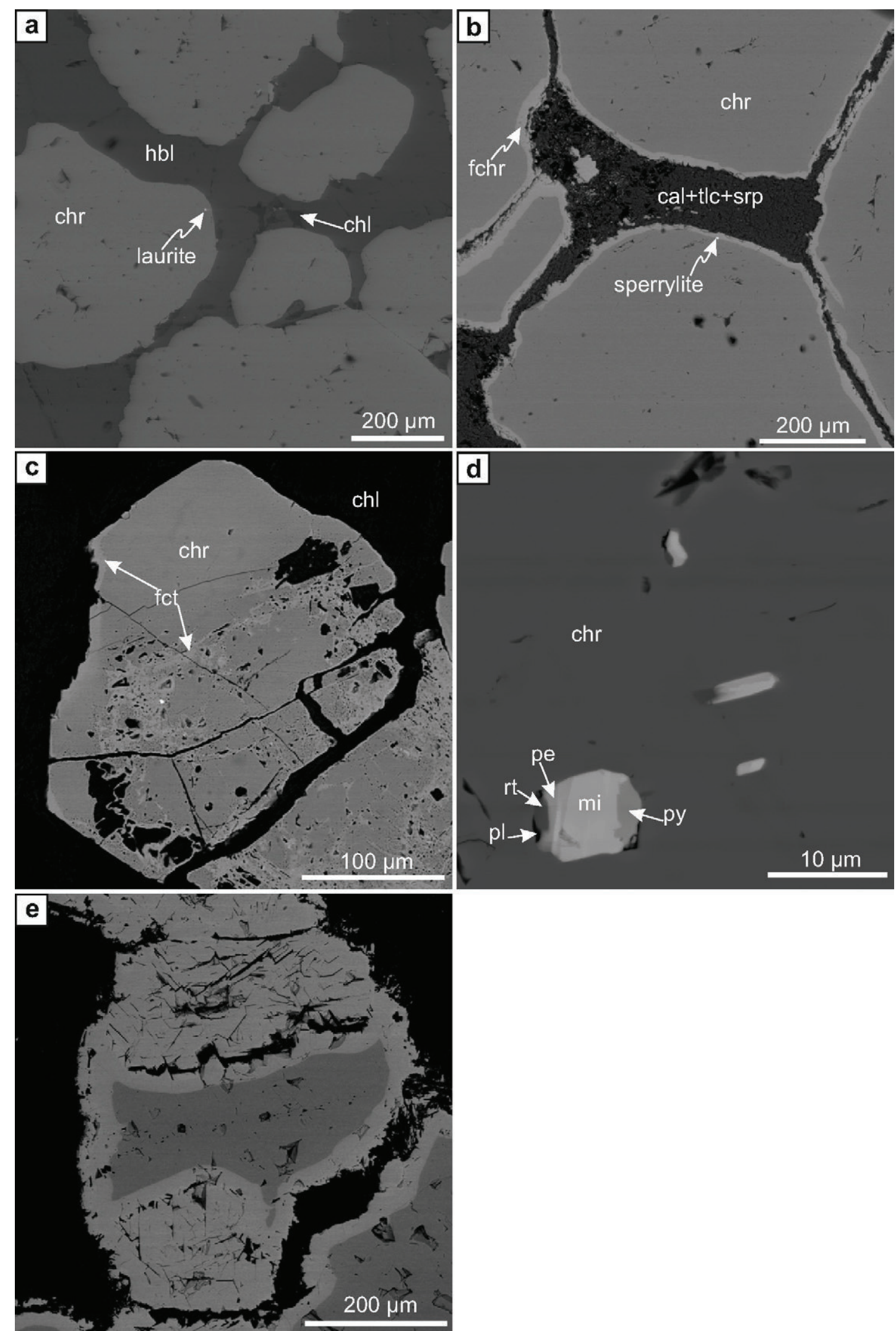

Fig. 5. Microphotographs of chromitites from the GAC. (a) Rounded chromite in amphibole-rich matrix (MA 273). Note the laurite inclusion in the inner rim of a chromite grain. (b) Rounded chromite grains with ferritchromit rim in a calcite-talc-serpentine matrix from a chlorite chromitite (MA 238). Sperrylite is exclusively present in the ferritchromit rim. (c) Spongy chromite from a brecciated chlorite chromite (MA 239). The ferritchromit rim develops around chlorite inclusions. (d) Sulphides (millerite replaced by pyrite and pentlandite), rutile and anorthite inclusions within a chromite grain from an amphibole chromitite (MA 273). (e) Chromite grain with a thick ferritchromit rim in a dessiminated chromitite (MA 422). chr: chromite, fct: ferritchromit, hbl: hornblende, chl: chlorite, cc: calcite, tlc: talc, srp: serpentine; rt: rutile; pl: plagioclase, mi: millerite, py: pyrite; pe: pentlandite. 
Table 2

Modal composition of silicate rocks from the GAC.

\begin{tabular}{|c|c|c|c|c|c|c|c|c|c|c|c|c|c|}
\hline & $\mathrm{Ol}$ & Cpx & Opx & cAmp & Antophyllite & Pl & $\mathrm{Qz}$ & Zrc & Ap & Spl & $\mathrm{Ilm}$ & Sulfides & \%Alt \\
\hline \multicolumn{14}{|c|}{ Olivine-amphibole rocks } \\
\hline Ma 426 & 62 & & & 25 & & & & & & 13 & & & 35 (srp) \\
\hline Ma 43 & 63 & & & 29 & & & & & & 8 & & & 60 (srp) \\
\hline Ma 259 & 75 & & & 17 & & & & & & 8 & & & 75 (srp) \\
\hline \multicolumn{14}{|c|}{ Spinel-amphibolite } \\
\hline Ma 25 & 7 & & & 67 & & 20 & & & & 6 & & & + \\
\hline Ma 264 & 23 & & 1 & 63 & & & & & & 13 & & & $15(\mathrm{Srp}+\mathrm{chl})$ \\
\hline \multicolumn{14}{|c|}{ Hornblendite } \\
\hline Ma 258 & & & & 100 & & & & & + & & + & & + \\
\hline \multicolumn{14}{|c|}{ Mela-amphibolites } \\
\hline Ma 28 & & & & 46 & 25 & 24 & & + & & & 5 & & 25 (ant) \\
\hline Ma 34 & & & & 62 & & 38 & & & + & & & + & $2(e p+a b)$ \\
\hline Ma 262 & & + & & 63 & & 32 & & + & + & & 4 & & 8 (ep, ab, msc) \\
\hline Ma 401 & & 15 & 26 & 28 & & 31 & & & & & & & + \\
\hline \multicolumn{14}{|c|}{ Leuco-amphibolites } \\
\hline Ma 29 & & & & 23 & & 77 & & & & & & & + \\
\hline Ma 27 & & & & 14 & & 86 & & & & & & + & + \\
\hline Ma 37 & 1 & & 13 & 33 & & 53 & & & & & & & 2 (srp, chl) \\
\hline \multicolumn{14}{|c|}{ Anorthosites } \\
\hline Ma 424 & & & & 1 & & 99 & & & & & & & 2 (ep, ab) \\
\hline Ma 423 & & & & 10 & & 90 & & & & & & & $5(\mathrm{ep}, \mathrm{ab})$ \\
\hline \multicolumn{14}{|c|}{ Fine-grained amphibolite } \\
\hline Ma 256 & & 10 & & 66 & & 24 & & & & & + & & 7 (ep, ab) \\
\hline Ma 267 & & 3 & 16 & 45 & & 36 & & & & & + & & $8(\mathrm{ep}, \mathrm{ab})$ \\
\hline Ma 408 & & 4 & 15 & 47 & & 34 & & & & & & + & $11(\mathrm{ep}, \mathrm{ab})$ \\
\hline Ma 412 & & 3 & 14 & 47 & & 36 & & & & & & + & $12(\mathrm{ep}, \mathrm{ab})$ \\
\hline Ma 435 & & & 27 & 41 & & 32 & 1 & & + & & + & & + \\
\hline
\end{tabular}

\%Alt: modal proportion of secondary low temperature phases (the nature of the phases is indicated between brackets).

+: accessory; srp: serpentine; ant: antophyllite; chl: chlorite, ep: epidote, ab: albite, msc: muscovite.

rotation (SGR) recrystallization, the latter being shown by the presence of small polygonal grains bordering the larger porphyroclasts. Sample MA 423 (Table 2) is an anorthosite with $\sim 8$ vol.\% of small prismatic green amphibole patches replacing a former larger clinopyroxene. Plagioclase is polyhedral with sharp straight grain boundaries. It shows evidence for subgrain rotation recrystallization (SGR), leading to the presence of both large deformed grains (up to $1 \mathrm{~cm}$ long) and small unstrained neoblasts.

Leuco-amphibolites (Fig. 6e) are characterized by the association of green-brown amphibole (14-33 vol.\%) and plagioclase (53-86 vol.\%), sample MA 37 showing additional granular orthopyroxene. Plagioclase is largely dominant over amphibole; no oxide has been observed. Textural evidence suggests that green amphibole progressively consumed brown amphibole during retrograde phase. Two samples (MA27 and 29) have a bimodal size distribution of plagioclase with slightly lobate strained polyhedral porphyroclasts surrounded by neoblasts formed by SGR. MA 37 sample displays a strong shape preferred orientation of both plagioclase aggregates and amphibole, plagioclase being unstrained and polyhedral. Epidote and albite are common low-temperature alteration phases of plagioclase in this sample.

\subsection{Fine-grained amphibolites ( $\mu$ amphibolites)}

Samples MA 267, 408 and 412 show the metamorphic association plagioclase + brown amphibole + clinopyroxene + orthopyroxene+ilmenite (Fig. 6f, Table 2). Former porphyroclasts of clinopyroxene (up to $1 \mathrm{~mm}$ wide) are surrounded by a fine-grained granulitic matrix of polygonal plagioclase, granular orthopyroxene and brown amphibole blasts, the latter clearly consuming large clinopyroxene. Samples MA 238 and 435 show a more equilibrated texture characterized by polygonal plagioclase and brown amphibole. Few relics of clinopyroxene are still observed in the core of amphibole. Quartz, apatite and pyrite are common accessory phases in these samples.

\section{Mineral chemistry}

For the following sections, analytical methods are provided as Supplementary material A and tables of microprobe analyses as Supplementary file B.

Supplementary data associated with this article can be found, in the online version, at http://dx.doi.org/10.1016/ j.precamres.2012.10.005.

\subsection{Chromite and other spinels}

Chromites from GAC chromitites define a large compositional field, the $\mathrm{Fe}^{2+} \#$ ranges from 53 to 98 and the $100 \times \mathrm{Cr} /(\mathrm{Cr}+\mathrm{Al})$ ratio from 40 to 75 (Fig. 7a) with low Ti contents ( $\max 0.54 \mathrm{wt} \% \mathrm{TiO}_{2}$ ). Compared to worldwide Archean and Paleoproterozoic chromites, those from the GAC are characterized by high Fe\# and low $\mathrm{Cr} /(\mathrm{Cr}+\mathrm{Al}$ ) (Fig. 7a) comparable to chromites from Fiskenaesset (Rollinson et al., 2010). Disseminated and brecciated chromitites show large compositional variations (ex: Fe\#: 62-96 in sample MA 422) with grains surrounded by a ferritchromit rim. Three compositional trends can be observed for brecciated and disseminated chromites (Fig. 7a): (i) a strong increase in $\mathrm{Cr} \#$ coupled to a slight increase of Fe\# towards ferritchromit compositions (Fe\#: 96, Cr\#: 99). (ii) A decrease of both $\mathrm{Fe \#}$ and $\mathrm{Cr} \#$ towards green spinels from spinel-amphibolites ( $\mathrm{Fe \# :} 30, \mathrm{Cr} /(\mathrm{Cr}+\mathrm{Al})$ : 0 ). (iii) Large variations in $\mathrm{Fe} \#(61-85)$ at constant $\mathrm{Cr} /(\mathrm{Cr}+\mathrm{Al})$ ratio ( 61-64) with an endmember composition represented by the massive chlorite-chromitite MA 226 (Fe\#: 53-57; $\mathrm{Cr} /(\mathrm{Cr}+\mathrm{Al})$ : 61-62) also characterized by the development of ferritchromit rims.

Massive and layered chromitites (Fig. 7b), either amphibole or chlorite-bearing, do not show compositional variation from 

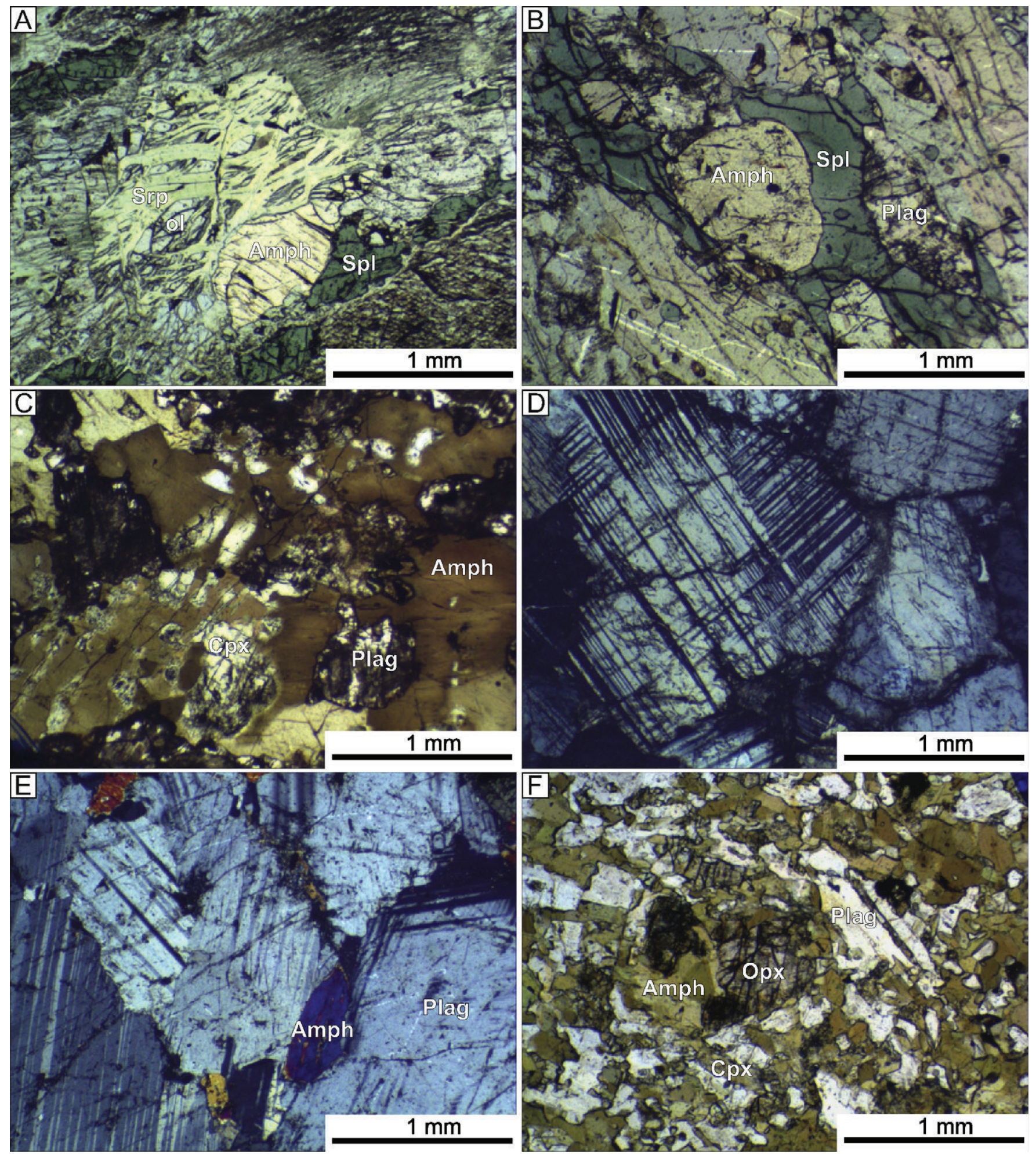

Fig. 6. Microphotographs of some silicate rocks from the GAC: (A) olivine-amphibole rock MA 426, note the former poikilitic texture; (B) spinel amphibolite MA 25; (C) mela-amphibolite MA 262 showing the progressive replacement of clinopyroxene by hornblende; (D) anorthosite MA 424; (E) leuco-amphibolite MA 29; (F) fine-grained opx-bearing amphibolite MA 435.

grain to grain in a given sample (ex: MA 273, Fe\#: 59.2-60.8; $\mathrm{Cr} /(\mathrm{Cr}+\mathrm{Al}): 51.8-52.8)$ and no chemical zoning within individual grains. Chromite in these samples are characterized by slight variation in $\mathrm{Cr} /(\mathrm{Cr}+\mathrm{Al})$ ratio (46-53) with $\mathrm{Fe \#} \mathrm{ranging} \mathrm{from} 59$ to 78; with the massive chlorite chromitite MA 238 showing maximal values for both $\mathrm{Fe \#}$ and $\mathrm{Cr} /(\mathrm{Cr}+\mathrm{Al}$ ) ratio (85-88 and 54-56, respectively). Chromite in massive and layered chromitites is the most similar to those from Archean layered anorthiste complexes (Fig. 7b).

On the $\mathrm{Fe}^{3+}-\mathrm{Cr}-\mathrm{Al}$ plot (Fig. 8), brecciated and disseminated chromites are located between massive chromitites and either ferritchromit ( $\mathrm{Al} \#$ : $0-10, \mathrm{Fe}^{3+} \#$ : $35-40$ ) or $\mathrm{Mg}-\mathrm{Al}$ green spinels ( $\mathrm{Al}$ : 90-100). As a whole, massive and layered chromitites are comparable to Fiskenaesset chromites though having low $\mathrm{Fe}^{3+} \#$ (4-10). 


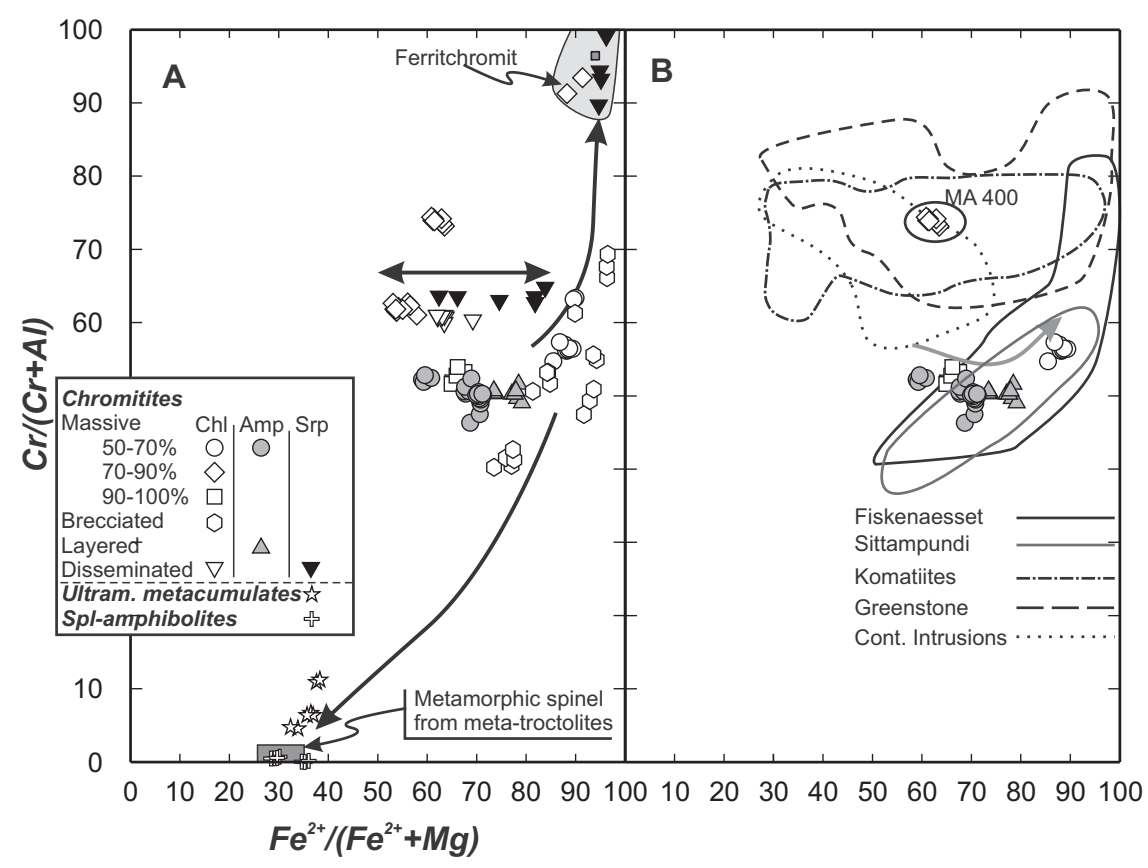

Fig. 7. Fe\# vs Cr\# plot for the GAC chromites and spinels. (A) Plot of all spinels and chromites from the GAC with the three metamorphic trends (thick black arrows) described in the text. (B) Plot of GAC chromites with preserved igneous composition and trend (thick grey arrow) compared to chromites from those from Archean/Paleoproterozoic terrains. Comparison fields are from Barnes and Roeder (2001) except for Fiskenaesset (Rollinson et al., 2010) and Sittampundi chromites (Dutta et al., 2011). The nature of the MA 400 chromites (metamorphic vs igneous) is discussed in the text. Chl, Amp and Srp refer to chlorite-, amphibole- and serpentine-chromitites, respectively.

On the Mg\# vs Al plot from chromites, the three trends observed for brecciated and disseminated chromites are well defined. The massive chromitites define a trend of constant Al for decreasing $\mathrm{Mg \#}$ and the sample with lowest Mg\# is characterized by lowest Al content (Fig. 9).

\subsection{Plagioclase and amphibole (Figs. 10 and 11)}

Plagioclase compositions range from $\mathrm{An}_{50}$ to $\mathrm{An} 98$ (Fig. 10) in the whole Guelb el Azib complex and are unzoned (less than 2 mol.\% An difference between core and rim, except in two retrogressed fine-grained and one mela-amphibolite) with no compositional difference between large strained grains and small

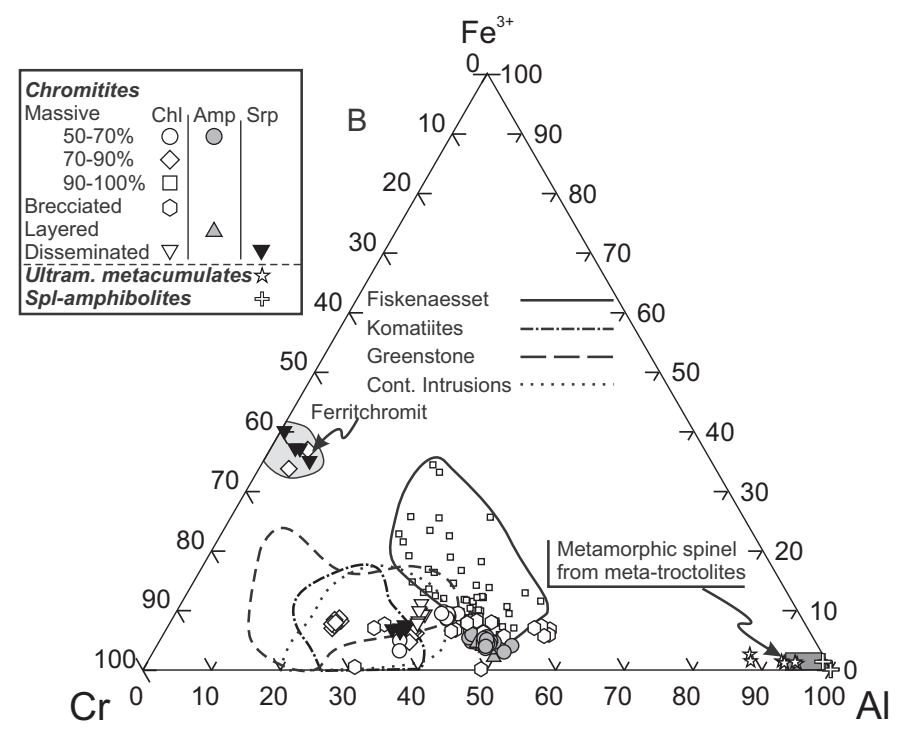

Fig. 8. $\mathrm{Fe}^{3+}-\mathrm{Al}-\mathrm{Cr}$ plot from the GAC spinels and chromites compared to chromites from Archean/Paleoproterozoic settings. Same references as in Fig. 7. polygonal new grains. The most An-rich plagioclase is found in the spinel-amphibolite MA 25 (An (17-98 ); it is associated with aluminous spinel and pargasitic amphibole (Mg\#: 90-93; up to 0.6 $(\mathrm{Na}+\mathrm{K})_{\mathrm{A}}$ a.p.f.u.). The plagioclase from mela-amphibolites varies from $A n_{56}$ to $A n_{92}$, the most calcic being found in the sample MA 401 which also has the most $\mathrm{Na}$ and $\mathrm{Al}$-rich amphibole (up to 1.9 ${ }^{\text {IV }} \mathrm{Al}$ a.p.f.u., Fig. 10). Amphibole from this group is highly variable in composition from one sample to another ( $\mathrm{Mg} \#$ : 43-78, ${ }^{\mathrm{IV}} \mathrm{Al}$ : 0.15-1.9 a.p.f.u.; Fig. 11). Again, plagioclase crystals are unzoned

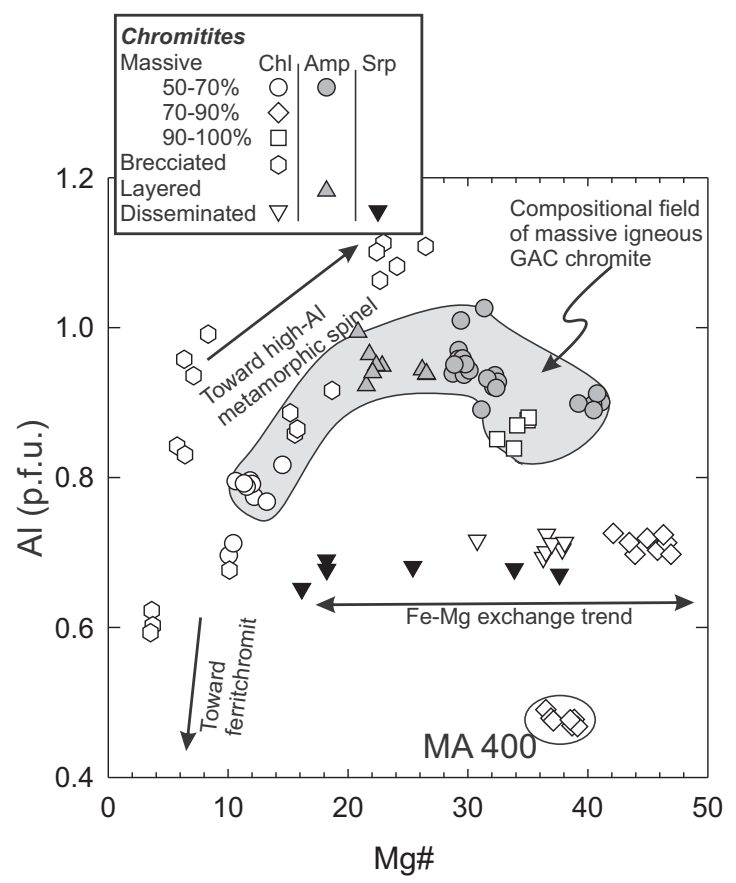

Fig. 9. Mg\# vs Al plot for chromites from the GAC. The grey field represents the composition of preserved igneous chromites. 
Al in amphibole (p.f.u.)

$\begin{array}{lllllllll}1.0 & 1.2 & 1.4 & 1.6 & 1.8 & 2.0 & 2.2 & 2.4 & 2.6\end{array}$
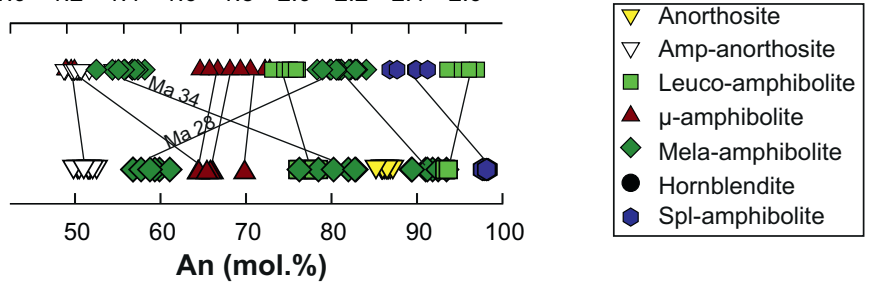

Fig. 10. Relationship between composition of amphibole and plagioclase in the GAC silicate rocks. The lines are joining plagioclase-amphibole pairs from a same sample.

and limited chemical variations (up to $4 \mathrm{~mol}$.\% An) from grain to grain are observed within a single rock. Leuco-amphibolites are characterized by plagioclase with compositional range $A n_{75-93}$, the most calcic plagioclase (MA 37) being associated with $\mathrm{Na}-$ and

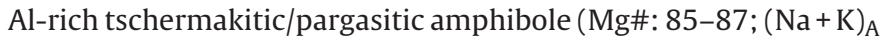
up to 0.5). The mono-mineralic anorthosite (MA 424) has calcic plagioclase $\left(A n_{85-87}\right)$, but the amphibole anorthosite (MA 423) has plagioclase with distinctly lower Ca contents $\left(\mathrm{An}_{50-52}\right) \mathrm{com}-$ pared to classical Archean anorthosites (Phinney et al., 1988), and is associated with a Al- and Na-poor Mg-hornblende (0.1-0.2 $(\mathrm{Na}+\mathrm{K})_{\mathrm{A}} ;{ }^{\mathrm{IV}} \mathrm{Al}: \sim 0.8$ p.f.u.). The different fine-grained amphibolites show calcic plagioclase $\left(\mathrm{An}_{64-70}\right)$ and $\mathrm{Al}$-rich $\mathrm{Mg}$-hornblende $(\mathrm{Mg} \#$ : 54-68) except for sample MA 435 which is characterized by Aland Na-poor amphibole (Mg\#: 78-80). Amphiboles composition from chromitites largely overlaps the one from spinel-amphibolite and olivine-amphibole rocks, they are magnesiohornblende and
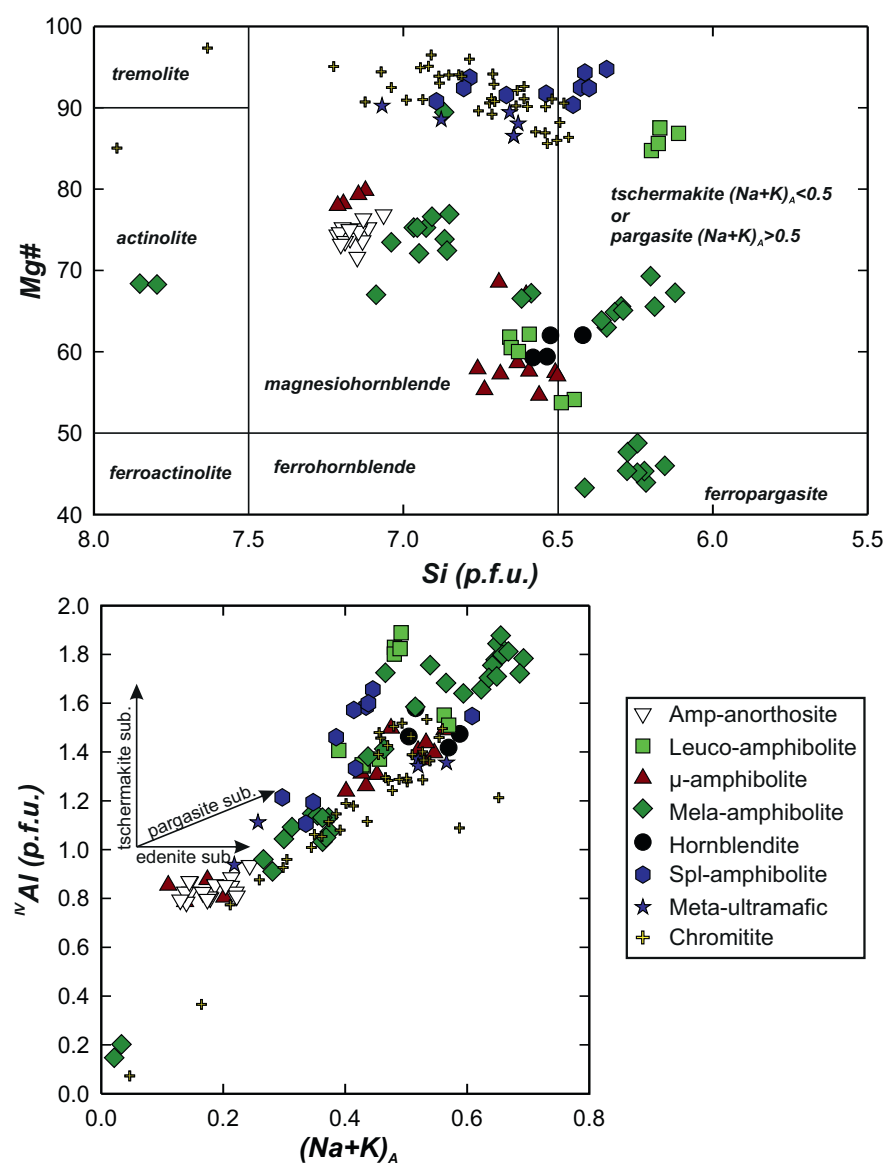

Fig. 11. Composition of amphiboles from the GAC. (A) Classification diagram from Leake et al. (1997). (B) $(\mathrm{Na}+\mathrm{K})_{\mathrm{A}}$ vs ${ }^{\mathrm{IV}} \mathrm{Al}$ plot showing the trends produced by various substitutions. tschermakite (Mg\#: 84-96; ${ }^{I V} \mathrm{Al}$ : 0.9-1.7 p.f.u.). Amphibole from the hornblendite MA 238 has a Fe-rich composition (Mg\#: 60) compared to other ultramafic samples (Mg\#>85; Fig. 11). A few amphiboles from mela-amphibolites and chromitites in chlorite-rich microdomains are actinolite or tremolite formed during low-temperature late stage alteration.

\subsection{Olivine}

Olivines have a restricted range of composition from $\mathrm{Fo}_{83}$ to $\mathrm{Fo}_{84}$ both in spinel-amphibolite MA 264 and metawebsterites 43 and 426. The olivine within chromitites is $\mathrm{Mg}$-rich compared to silicate rocks: $\mathrm{Fo}_{91}$ in sample MA 17 and $\mathrm{Fo}_{94}$ in sample MA 400. The $\mathrm{Cr}$ content is high in olivine from chromitites (up to $1.04 \mathrm{wt} \% \mathrm{Cr}_{2} \mathrm{O}_{3}$ ) compared to olivine from silicate rocks ( $\left.<0.04 \mathrm{wt} \% \mathrm{Cr}_{2} \mathrm{O}_{3}\right)$.

\subsection{Pyroxenes}

Clinopyroxenes from mela-amphibolites and fine-grained amphibolites are augites with $\mathrm{Mg \#}$ ranging from 0.70 to 0.80 ; they have low contents of non-quadrilateral elements (Al: 0.03-0.06 a.p.f.u. and Ti: 0.002-0.004 a.p.f.u.). Orthopyroxene from the spinel amphibolite MA 264 is the most magnesian (Mg\#: 0.84 ). Within the group of mafic rocks, the olivine-bearing leucoamphibolite has the most Mg-rich orthopyroxene (Mg\#: 0.76-0.78) compared to mela-amphibolite $(0.59-0.62)$ and fine-grained amphibolites (0.52-0.66). The Al content increases with decreasing $\mathrm{Mg \#}$ in Mg-rich samples (from 0.050-0.067 to 0.074-0.098 p.f.u.); it is significantly lower in mela- and fine-grained amphibolites (0.011-0.028 p.f.u.).

\section{P-T calculations and thermodynamic modelling}

Despite preserved igneous macrostructures, such as layering, scarce igneous textures and minerals, the rocks from the Guelb el Azib complex, are strongly metamorphosed under granulitic grade with subsequent retrogression under amphibolite and greenschist facies grade. The P-T calculations will thus only constrain the metamorphic conditions registered by the GAC complex. According to petrographical observations, samples from the GAC were subject to anhydrous granulitic grade metamorphism that is evidenced by granular opx-cpx-plag assemblages in mafic rocks and olivine-spinel-pargasite in ultramafic rocks. It was then affected by pervasive hydrous recrystallization in the low T granulite to amphibolite-facies conditions (growth of brown and green amphibole) and then subject to local recrystallization in the greenschist facies (rodingites, chlorite, epidote).

Amphibole-plagioclase thermometry of Holland and Blundy (1994) was used to compute equilibration temperature in GAC rocks. As recommended by the authors, plagioclase-amphibole pairs characterized by $X_{\text {An }}$ largely above 0.9 (MA 25: 0.97-0.98) were excluded of the calculations. The thermometer was applied to amphibole-anorthosite, fine-grained amphibolites, leuco-amphibolites and mela-amphibolites. Pressure has been fixed at 5 kbar (see below) but this calibration is only slightly pressure-dependent with a temperature increase of $7^{\circ} \mathrm{C} / \mathrm{kbar}$. The calculated temperatures vary from 650 to $960^{\circ} \mathrm{C}$ (Fig. 12), the melaamphibolites showing the highest values and most temperatures fall within the range $750-850^{\circ} \mathrm{C}$ (granulitic conditions). The plagioclase and amphibole compositions from mela-amphibolite MA 401 have mineral compositions close to the limits of applicability of this thermometer $\left(X_{\mathrm{An}}: 0.89-0.93\right.$, with most values at $0.91 ;{ }^{\text {IV }} \mathrm{Al}$ in amphibole between 1.66 and 1.84 a.p.f.u.). Computed temperatures range from 960 to $1000^{\circ} \mathrm{C}$ in this sample but the uncertainty is 


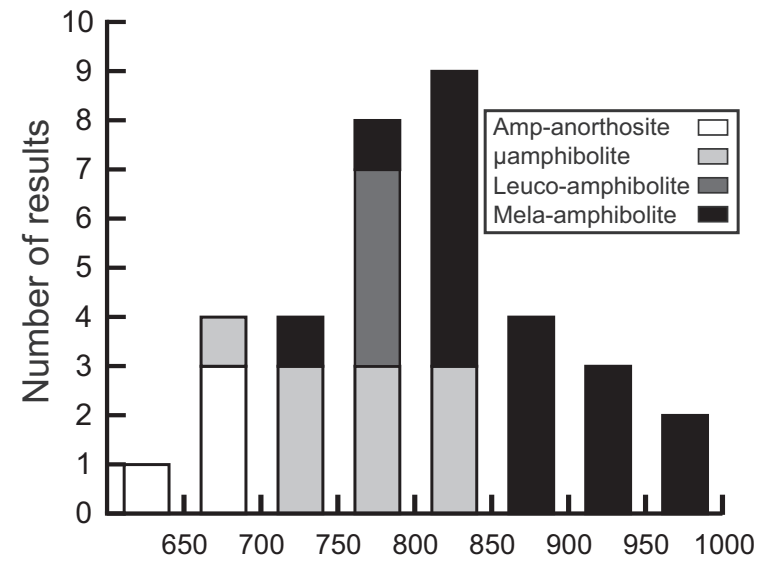

Fig. 12. Bar plot of temperatures calculated with hornblende-plagioclase thermometry (Holland and Blundy, 1994) for the various rock types of the Guelb el Azib complex. Pressure is fixed at 5 kbar.

probably larger than the one recommended by Holland and Blundy $(1994)\left( \pm 40^{\circ} \mathrm{C}\right)$

Pressure is difficult to estimate for the metamorphic assemblages lacking baro-dependent minerals. One olivine leucoamphibolite sample (MA 37) has been selected to draw a fixed composition phase diagram because it has a low variance assemblage $(\mathrm{pl}+\mathrm{amph}+\mathrm{ol}+\mathrm{opx})$ compared to other samples. The pseudosection (Fig. 13) has been built with Perple_X (Connolly, 2005) using the thermodynamic dataset of Holland and Powell (1998, updated in 2003) and the solution models of Diener et al. (2007) for amphibole, of Holland and Powell (1996) for ortho- and clino-pyroxene and of Holland and Powell (2003) for plagioclase. The stability of the $\mathrm{pl}+\mathrm{amph}+\mathrm{opx}+\mathrm{ol}$ assemblage occupies a small portion of the grid: below $6.6 \mathrm{kbar}$ at $800-910^{\circ} \mathrm{C}$. Mineral isopleths have been drawn for the $\mathrm{Mg} \#$ of orthopyroxene; the isopleth that

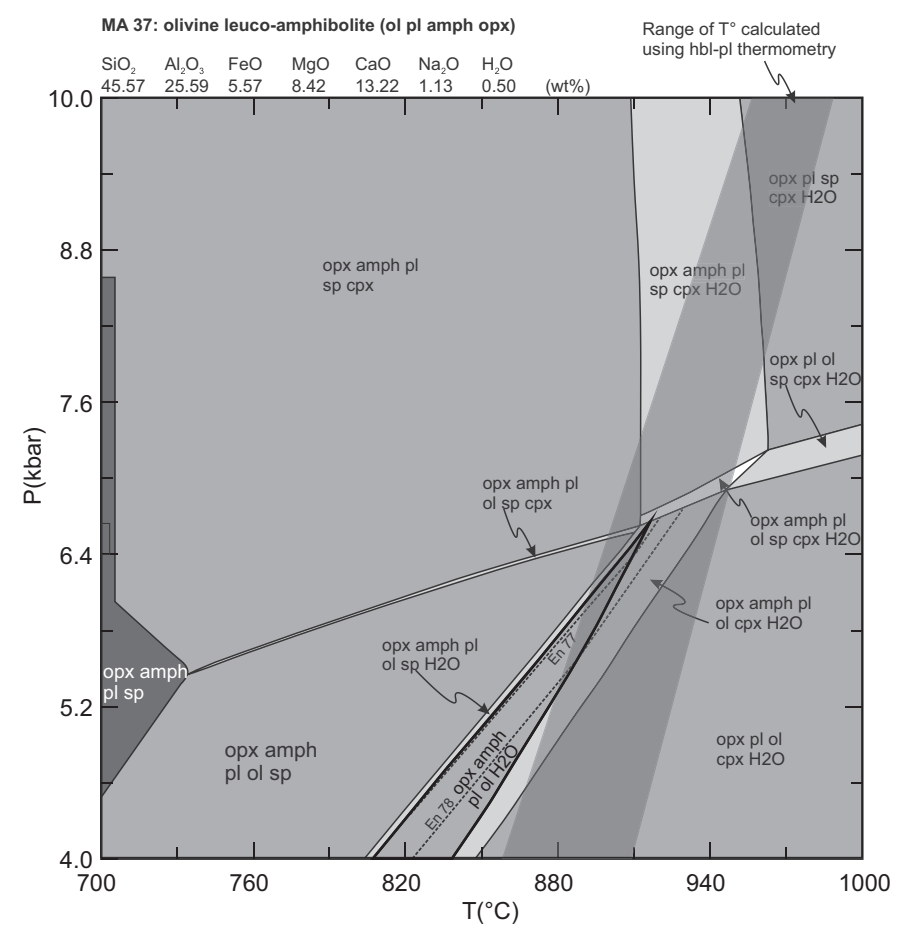

Fig. 13. Pseudosection built with Perple_X for sample MA 37. The grey shaded area represents the temperature range measured with hornblende-plagioclase thermometry for the same sample. The stability field for the assemblage observed in sample MA 37 is outlined by a thick line. matches the composition measured by microprobe $\left(\mathrm{En}_{77}\right)$ crosses the $\mathrm{pl}+\mathrm{amph}+\mathrm{opx}+\mathrm{ol}$ field in the highest pressure part of the stability field. When combining the results of hornblende-plagioclase thermometry (shaded grey area in Fig. 13) and those from phase diagram calculation, the best fit for pressure is between 5.2 and 6.4 kbar. This pressure estimation is in good agreement with previous studies on metapelitic rocks of the Amsaga area ( $5 \pm 1 \mathrm{kbar}$; Potrel et al., 1998) but the maximal temperature estimations from this author are lower $\left(800 \pm 50^{\circ} \mathrm{C}\right)$ compared to ours $\left(880-910^{\circ} \mathrm{C}\right)$. The diagram also support that the growth of brown amphibole at the expense of pyroxene is a retrograde reaction linked to both temperature decrease and hydration within the granulite-facies space (Fig. 13), as deduced from petrographic observations.

\section{Concentration and speciation of platinum-group elements}

Platinum-group minerals (PGM) have only been observed in massive and layered chromitites. The most abundant PGM is laurite $\left(\mathrm{RuS}_{2}\right)$ which occurs as small $(<5 \mu \mathrm{m}$, mostly $2-3 \mu \mathrm{m}$ wide $)$ and euhedral inclusions (Fig. 14a and b) in the core and the rim of the chromite.

Quantitative electron microprobe analyses have not been undertaken due to the small size of the inclusions that approaches the diameter of microprobe beam. Semi-quantitative analyses with energy dispersive spectrometer (EDS) show that iridium and osmium are the most common elements substituted to $\mathrm{Ru}$ into laurite: the range of measured composition is $\left(\mathrm{Ru}_{0.80-0.87} \mathrm{Os}_{0.09-0.12} \mathrm{Ir}_{0.04-0.08}\right) \mathrm{S}_{2}$. Sulfoarsenides of the irarsite (Ir, Rh)AsS-hollingworthite (RhAsS) solid solution are the second most frequent PGM in the Amsaga chromitites. They are found as small overgrowths on laurite (Fig. 14a and b) or as isolated anhedral grains $(<2 \mu \mathrm{m}$ wide) sometimes associated with rutile and anorthite (Fig. 14c). The composition of irarsites measured by EDS in samples MA 420 and 226 corresponds to the formula $\mathrm{Ir}_{0.60-0.69} \mathrm{Rh}_{0.31-0.40}$ AsS. Sperrylite (PtAs 2 ) is the coarser (up to $15 \mu \mathrm{m}$ long) PGM found (Fig. 14d) and is located in the ferritchromit rim of spinel from samples MA 273 and 238. Minute $(<1 \mu \mathrm{m})$ rustenburgite $\left(\mathrm{Pt}_{3} \mathrm{Sn}\right)$ has also been observed forming small grains overgrowing laurite in sample MA 226.

Six bulk chromitites samples have been analysed for bulk PGE content. Three subgroups can be distinguished on the basis of the chondrite-normalized PGE pattern (Fig. 15):

- MA 226, 400 and 422 show a pronounced Ru peak with low PPGE (Rh, Pt, Pd) compared to IPGE (Ir, Ru): i.e. low (Pt/Rh) $)_{\mathrm{N}}$ ratios with $(\mathrm{Rh} / \mathrm{Ir})_{\mathrm{N}}$ close to unity $(0.5-1.9)$ and high $(\mathrm{Pt} / \mathrm{Pd})_{\mathrm{N}}$ ratio (3.2-3.4). - The two samples containing sperrylite (MA 273 and MA 238) are characterized by high PGE contents compared to the previous group and high PPGE/IPGE ratios ((Rh/Ir $)_{\mathrm{N}}$ : 3.5-4.9).

- The layered chromitite MA 425 (found within an anorthositic unit) has the lowest PGE contents with a more or less flat profile and a slight positive peak for $\mathrm{Ru}$.

\section{Discussion}

\subsection{Impact of metamorphism on chromite compositions and mineral assemblages}

Four different trends can be observed in Fig. 7a and b for chromite compositions. The increase in both $\mathrm{Fe \#} \mathrm{and} \mathrm{Cr} /(\mathrm{Cr}+\mathrm{Al})$ ratio towards ferritchromit composition can be ascribed to reequilibration during low-temperature hydrous metamorphism. Indeed, many chromites from the samples following this trend show spongy textures characterized by (i) numerous inclusions of 

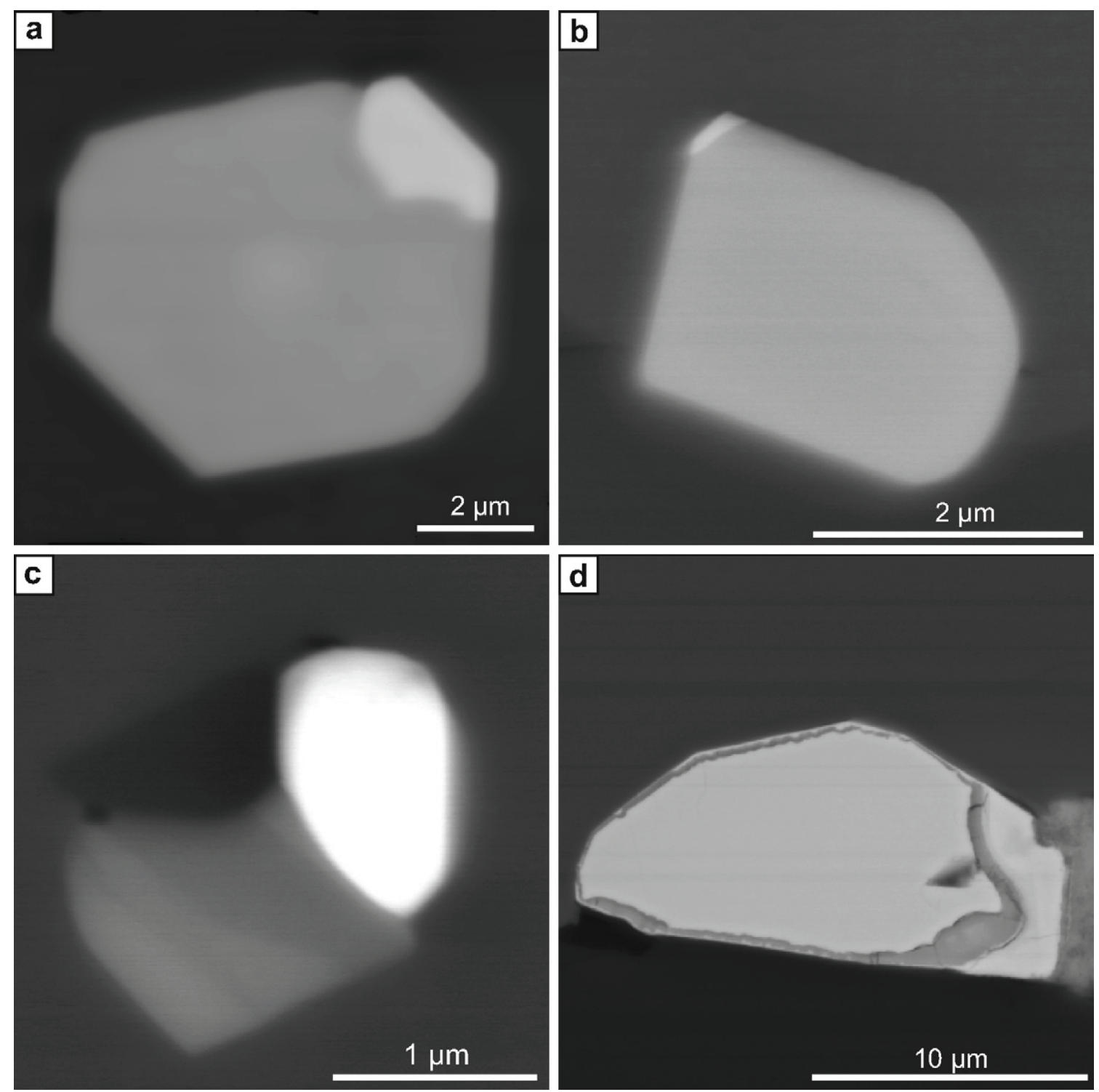

Fig. 14. Backscattered electron images of PGM enclosed in chromite grains: (a) euhedral laurite with irarsite overgrowth (MA 420); (b) euhedral laurite with hollingworthite bud (MA 226); (c) laurite (white) associated with rutile (grey) and plagioclase (black) in a chromite (dark grey) (MA 420); (d) sperrylite grain surrounded py Pd oxides within the ferritchromit rim (sample MA 273).

chlorite, (ii) thick rim of ferritchromit composition, (iii) strong compositional variation from grain to grain. Ferritchromit rims or grains are often interpreted as low grade reequilibration of chromite under an oxidizing environment (see Mukherjee et al., 2010). Chromite lying along this trend cannot be used to infer the composition of their parental magma.

Some ultramafic metacumulates have preserved olivine-amphibole assemblages with an aluminous spinel. The composition of these spinels and the association of high-Al amphibole and green aluminous spinel with olivine are typical of high temperature (granulite to amphibolites facies conditions) meta-troctolites (Tenthorey et al., 1996; Berger et al., 2010; see Figs. 7a and 8) and sakenites (Giuliani et al., 2006; Raith et al., 2008). Green spinels from spinel-amphibolite and olivine-amphibolite are strongly aluminous and depleted in $\mathrm{Cr}$. Their composition suggests that high-grade metamorphism has led to enrichment in the spinel end-member with leaching of $\mathrm{Cr}$, a shift comparable to the replacement trend described by Rollinson et al. (2002) in metamorphosed Archean chromitite-anorthosite associations from Greenland. At variance with our interpretation, these authors interpret the replacement trend as a result of late magmatic interaction between high-Cr spinels and evolved interstitial melt. Recent studies on chromitites from the Archean Sittampundi complex, in India (Dutta et al., 2011) also propose a metamorphic origin for the aluminous green-blue spinel. Chromite composition trending towards these $\mathrm{Mg}-\mathrm{Al}$ spinels in Fig. 7a (i.e. brecciated chromitite MA 436) are interpreted to have been partially equilibrated during high grade metamorphism and they will not be used to calculate parental magma compositions.

The strong variations in $\mathrm{Fe \#}$ for a constant $\mathrm{Cr} /(\mathrm{Cr}+\mathrm{Al})$ ratio observed for disseminated chromitites (Fig. 7a) also characterized by the development of ferritchromit rims are more difficult to interpret. Because these samples show strong compositional variation from grain to grain with the frequent development of a ferritchromit rim, one can infer that their composition has been modified by metamorphism. One of these sample (MA 422) is a serpentine-bearing disseminated chromitite probably representing a former olivine-chromitite. Fe-Mg exchange between spinel and olivine is a quick reaction that led to partial reequilibration of these two phases at PT conditions (Ozawa, 1983). As olivine 


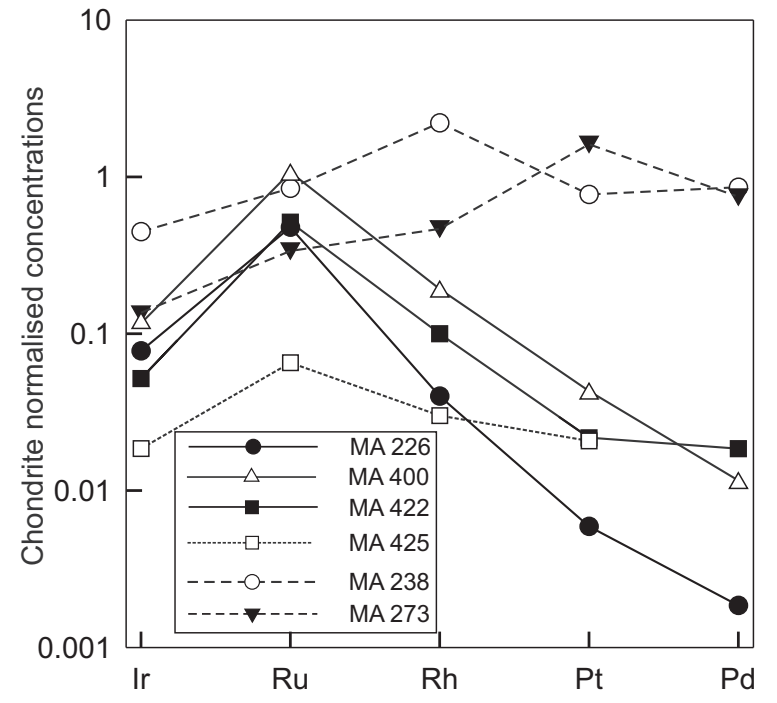

Fig. 15. PGE pattern of selected chromitites from the GAC. Normalization values are from Naldrett and Duke (1980).

contains only minor amounts of $\mathrm{Al}$ and $\mathrm{Cr}$, reequilibration with spinel will not modify the $\mathrm{Cr} /(\mathrm{Cr}+\mathrm{Al})$ ratio of the latter but will strongly affect the partition of $\mathrm{Fe}$ and $\mathrm{Mg}$. The disseminated and the massive chromitite (MA 226) lying on the Fe-Mg exchange trend with constant $\mathrm{Cr} /(\mathrm{Cr}+\mathrm{Al})$ ratios represent chromite that has been reequilibrated with a low $\mathrm{Al}$ and $\mathrm{Cr}$ but high $\mathrm{Fe}-\mathrm{Mg}$ phase, probably olvine and/or clinopyroxene.

The massive chromitites have chromite as main phase (up to 95 vol.\%). Reequilibration with a minor host silicate phase will thus have minor effects on the composition of these chromites. Moreover, massive chromitites (except MA 226) show homogeneous chromite compositions in a given sample, they do not show ferritchromit rims, they are not affected by low-temperature growth of chlorite as in brecciated chromitites and they are very comparable to Fiskenaesset and Sittampundi chromites with preserved igneous compositions (Fig. 7b; Rollinson et al., 2010; Dutta et al., 2011). The last trend observed for massive chromite can thus be interpreted as a preserved igneous feature.

Silicate rocks have also been affected by HT and LT metamorphism. The composition of their minerals cannot be used to estimate compositions of their parental melts The granular opx-cpx-plag assemblages in fine-grained amphibolites and mela-amphibolites argue for a peak HT-MP granulite grade metamorphism: up to $910^{\circ} \mathrm{C}$ at 5-6 kbar in anhydrous environment (Fig. 13). Pyroxenes were nearly totally consumed to amphibole during a retrogressive hydrous event in the amphibolite and lower granulite facies conditions $\left(900-650^{\circ} \mathrm{C}\right)$. A few samples have preserved evidences for direct replacement of clinopyroxene by amphibole (Fig. 6c), which is concordant with a retrograde evolution in the pseudosection built for MA 37 bulk composition (Fig. 13).

There is a relationship between the An content of plagioclase and the $\mathrm{Na}$ and $\mathrm{Al}$ contents of co-existing amphibole from fine-grained, leuco- and mela-amphibolites, the most calcic plagioclase being at equilibrium with a Na- and Al-rich amphibole (Fig. 10). This certainly indicates a metamorphic origin for the amphibole in those rocks, the Na enclosed in former igneous plagioclase has been transferred into amphibole thanks to a pargasite substitution during clinopyroxene breakdown (the latter cannot deliver large quantities of $\mathrm{Na}$ ). The An content of the plagioclase in amphibole-bearing rocks thus no more reflects the original igneous composition, as attested by nearly pure anorthite composition (0.97-0.98 An mol.\%; Fig. 10) of plagioclase in spinel-amphibolite MA 25. Exceptions are observed in Fig. 10 for two mela-amphibolites (MA 28 and MA 34). This anomaly cannot be explained by different equilibration temperatures in these samples $\left(800-850^{\circ} \mathrm{C}\right)$ compared to other amphibolites $\left(720-930^{\circ} \mathrm{C}\right)$ but could reflect, however, the preservation of igneous amphibole that has been reequilibrated with plagioclase during granulite-facies metamorphism.

As discussed above, olivine-amphibole rocks and spinel amphibolites share many characteristic with meta-troctolites metamorphosed under HT amphibolite to granulite grade.

The origin of chromite-amphibole association in some chromitites is more ambiguous. These samples are found in close spatial association with anorthosites. In the Fiskenaesset complex, chromitites in anorthosites have amphibole as matrix phase (see Rollinson et al., 2010). On the basis of comparison with worldwide unmetamorphosed amphibole-chromitite occurrences, Rollinson et al. (2010) proposed that amphibole from chromitites is of igneous origin. Dutta et al. (2011) however observed textural evidence for clinopyroxene replacement by amphibole in chromitites from the Sittampundi complex. In our samples, there is no textural evidence preserved but the amphibole composition matches the one of spinel-amphibole metamorphic rocks (see Fig. 11). We therefore propose that amphibole in chromitite is of metamorphic origin in the Guelb el Azib complex.

As a conclusion, only the mono-mineralic rocks (or nearly so) are expected to have preserved their original igneous mineral compositions. This is most probably the case for the anorthosites and the chromites from massive and layered chromitites.

\subsection{Determination of the chromitite parental melts}

Kamenetsky et al. (2001) have shown that the Al and Ti contents of igneous chromites are linearly correlated to that of the melt. Maurel and Maurel (1983) proposed an equation to compute the $\mathrm{FeO} / \mathrm{MgO}$ ratio in the parental melt of igneous chromites. The value of this ratio in the spinel is however strongly sensitive to variations oxygen fugacity and, as a consequence, large errors are attached to the determination of the $\mathrm{FeO} / \mathrm{MgO}$ ratio in the melt. Only primary chromites following the proposed igneous trend (Fig. 7b) and showing no petrographical nor chemical evidence for hydrothermal alteration, oxidation or high grade metamorphism were used for the calculations. Few rutile exsolutions were observed in chromites, the $\mathrm{TiO}_{2}$ content of the equilibrium melt is most probably underestimated (see Rollinson et al., 2002) and will therefore not be used as a discriminating factor. Furthermore, evolved chromites with high Fe\# show a strong decrease of their Al content. They have probably co-crystallized with plagioclase and their $\mathrm{Al}$ content has been buffered by the feldspar. Consequently, only the results for the chromites crystallized during and before the $\mathrm{Al}$ peak (Fig. 9) are plotted in the $\mathrm{FeO} / \mathrm{MgO}$ vs $\mathrm{Al}_{2} \mathrm{O}_{3}$ diagram (Fig. 16). The melt in equilibrium with the most primitive chromite (highest Mg\#, MA 273) has 15 wt $\% \mathrm{Al}_{2} \mathrm{O}_{3}$ and plots both in the field of Archean tholeiites (Fig. 16). There is almost no increase of $\mathrm{Al}_{2} \mathrm{O}_{3}$ contents with increasing $\mathrm{FeO} / \mathrm{MgO}$ ratio in melts that crystallized chromitites, up to $15-16 \mathrm{wt} \%$ for the most evolved chromite (lowest Mg\#, MA 238) parental melts, confirming that there was no massive fractionation of plagioclase during this sequence of differentiation. All calculated melts fall in the field of Archean tholeiite in Fig. 16.

Chromites from MA 400 are not in equilibrium with common Archean basic-ultrabasic melts (Fig. 16). They also plot outside the igneous trend formed by other massive chromitites (Fig. 9). Although there is no petrographic evidence for metamorphic reequilibration, the chromite from this sample probably underwent metamorphic reequilibration with host phase. It is indeed the most $\mathrm{Fe}^{3+}$-rich spinel of all massive chromitites (up to 0.17 a.p.f.u.). 


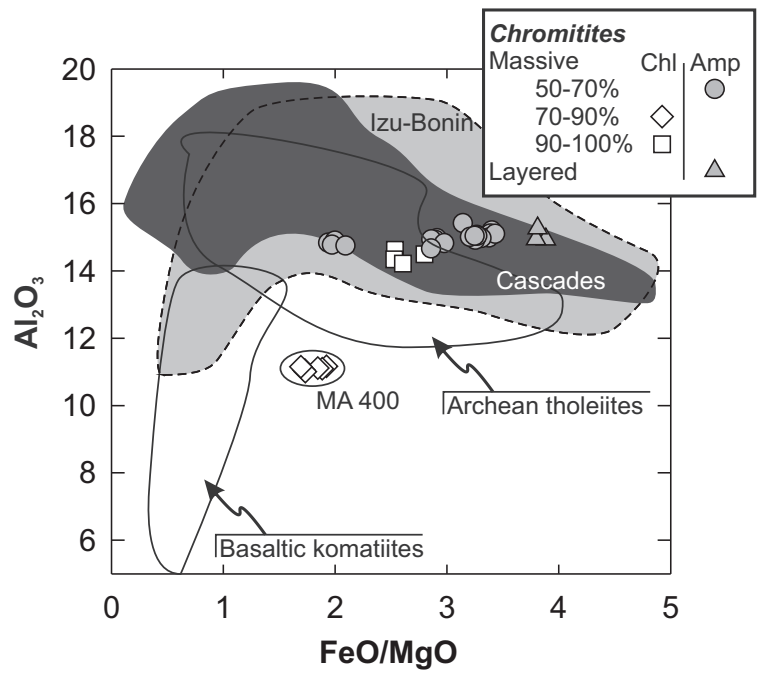

Fig. 16. Composition of the melt in equilibrium with GAC chromites with preserved igneous composition (Fig. 7b) compared to basaltic komatiites, Archean tholeiites, Izu-Bonin and Cascades arc magmas (data from the online GEOROC database). The most evolved chromite from sample MA 226 has not been plotted in this diagram because it has probably been crystallizing along with plagioclase.

\subsection{Inferences on the primary magma and the conditions of crystallization}

The igneous chromite with highest Mg\# crystallized from a melt having a Mg\# around 47. This is too low to be in equilibrium with a classical mantle peridotite with pyrolitic or depleted harzburgitic composition. The melt that has crystallized the igneous chromite was either evolved or it has been formed by a pertubated Fe-rich mantle. The GAC also present large volumes of ultramafic rocks in the form of serpentinite (former spinel-bearing olivine-rich rocks) and ultramafic metacumulates (former olivine-plagioclase-spinel rocks). It is not possible to estimate the composition of their parental melts because of the strong imprint of both HT granulitic metamorphism and late greenschist facies alteration. However, their presence indicates at least that the primitive magma was more Mg-rich compared to the one that crystallized chromites.

Using information on rocks with preserved igneous mineralogy and/or mineral composition and on the nature of the igneous precursors of metamorphic rocks, the primary magma and is liquid line of descent must fit to the following observations:

(i) The melt has crystallized primitive ultramafic olivine-rich cumulates (olivine-pyroxenes-spinel \pm plagioclase rocks), chromites, mela- and leuco-gabbros (plagioclase and pyroxene, \pm amphibole rocks) and highly calcic anorthosites (Fig. 4). The hornblendites (amphibole cumulates or meta-pyroxenite) form only small elliptical bodies within ultramafic units and are consequently not a major constituent of the GAC.

(ii) The anorthosite and some leucogabbros have a highly calcic plagioclase. The formation of such rocks requires an aluminous parental melt with high $\mathrm{Ca} / \mathrm{Na}$ ratio. Massive fractionation of clinopyroxene did certainly not occur before plagioclase saturation because it would have strongly decreased the $\mathrm{Ca} / \mathrm{Na}$ ratio of the melt parental to the anorthosite.

(iii) The compositional trends observed for chromitites (decrease in $\mathrm{Al}$ content for the most Fe-rich igneous chromites), together with field observation, suggest that plagioclase saturation in the melt was reached during chromite crystallization (Fig. 9).

(iv) Compared to Archean and Paleoproterozoic chromites from komatiites, greenstone belts and layered intrusions, those from Guelb el Azib have higher Fe\# and lower $\mathrm{Cr} \#$ mean values
(Figs. 7 and 8). The parental melt to chromitites has thus high $\mathrm{Fe} / \mathrm{Mg}$ ratio and/or large amount of a phase with low $\mathrm{Fe} / \mathrm{Mg}$ ratio (olivine) has been fractionated from a high-Mg melt before chromite saturation (as suggested by the presence of ultramafic olivine-rich cumulates in GAC).

Considering these lines of evidence, the primitive melt should have been an Mg-rich, high alumina basaltic melt. Such a composition explains the presence of former olivine-rich meta-igneous rocks co-existing with large volume of plagioclase-rich metagabbros and anorthosites. In addition, experiments have shown that increasing water contents in the melt promotes the crystallization of Ca-rich plagioclase (see Grove and Baker, 1984; Sisson and Grove, 1993; Takagi et al., 2005; Feig et al., 2006). This is compatible with the probable presence of few igneous amphiboles in mela-amphibolites MA 28 and 34 and with the occurrences of hornblendite that are commonly formed from hydrous magmas in similar context (see Polat et al., 2012). Increasing water content leads to the enlargement of the temperature interval of pyroxene crystallization and reduces the window where plagioclase and chromite co-precipitate (Berndt et al., 2005; Feig et al., 2006; Hamada and Fujii, 2008). The primitive melt was thus not saturated with water, it was slightly hydrous.

Experimental studies of subalkaline melt crystallization demonstrate that increasing pressure tends to stabilize pyroxenites over olivine-plagioclase cumulates and leads to the formation of igneous garnet (Muntener et al., 2001; Villiger et al., 2004, 2007; Alonso-Perez et al., 2009). Pyroxenites are absent or minor in the GAC, garnet was not observed neither as igneous nor metamorphic phase while metamorphosed olivine-plagioclase rocks are present. We can thus infer a low pressure of crystallization, at depth corresponding to upper or middle crust.

Formation of the GAC through low pressure crystallization of a hydrous magma is in agreement with previous studies on similar complexes (Weaver et al., 1981; Rollinson et al., 2010; Polat et al., 2011; Dutta et al., 2011). The melt became subsequently enriched in Al through fractional crystallization of olivine and chromite and reached a composition matching that of Archean tholeiites (Fig. 16, see below) just before plagioclase saturation. An Archean tholeiite composition for the Archean anorthosite parental melt agrees with results obtained by Henderson et al. (1976), Ashwal (1993) and Rollinson et al. (2010) on the basis of inverted REE contents of plagioclase.

\subsection{PGM crystallization and PGE fractionation}

PGM co-crystallized along with chromites and base metal sulphides. Detailed observations with the electron microscope and bulk PGE patterns have shown that three phases of PGE mineralization can be distinguished in chromitites.

(i) The earliest one is evidenced by the formation of euhedral laurite and millerite (Fig. 14a and b). The shape of laurite together with experimental results (Brenan and Andrews, 2001) show that laurite is a high-temperature igneous PGM in the GAC as in ophiolitic chromitites where it is entrapped during magmatic growth of chromite (Augé, 1985). This mineralization phase has characteristic PGE patterns with high IPGE contents compared to PPGE (samples MA 226, 400 and 422; Fig. 15) which fits relatively well with that of chromitites from ophiolites, komatiites and layered intrusions (Cabri, 2002; Naldrett et al., 2012; Pagé et al., 2012). Chromite crystallized in komatiitic and tholeiitic melts concentrates IPGE. These elements may be present in chromite as solid solution (Pagé et al., 2012; Brenan et al., 2012) or co-crystallized with IPGE minerals due to their low solubilities in basic magmas (Pagé et al., 
Table 3

Major and trace element composition of bulk chromitite samples.

\begin{tabular}{|c|c|c|c|c|c|c|c|c|}
\hline & MA 226 & MA 238 & MA 240 & MA 241 & MA 273 & MA 400 & MA 422 & MA 425 \\
\hline \multicolumn{9}{|c|}{ Major elements (wt\%) } \\
\hline $\mathrm{SiO}_{2}$ & 3.02 & 8.94 & 3.33 & 12.85 & 12.14 & 1.65 & 19.71 & 10.23 \\
\hline $\mathrm{TiO}_{2}$ & 0.31 & 0.36 & 0.29 & 0.24 & 0.54 & 0.38 & 0.17 & 0.44 \\
\hline $\mathrm{Al}_{2} \mathrm{O}_{3}$ & 16.23 & 17.11 & 23.54 & 22.17 & 20.56 & 11.77 & 7.29 & 22.12 \\
\hline $\mathrm{Fe}_{2} \mathrm{O}_{3}$ & 27.54 & 25.13 & 30.59 & 24.39 & 19.58 & 24.59 & 26.66 & 23.57 \\
\hline $\mathrm{MnO}$ & 0.51 & 0.69 & 0.61 & 0.69 & 0.32 & 0.44 & 0.50 & 0.37 \\
\hline $\mathrm{MgO}$ & 10.03 & 10.30 & 4.92 & 11.53 & 11.68 & 8.39 & 19.86 & 8.02 \\
\hline $\mathrm{CaO}$ & 0.10 & 0.09 & 0.12 & 0.18 & 2.79 & 0.13 & 1.21 & 2.54 \\
\hline $\mathrm{Na}_{2} \mathrm{O}$ & 0.14 & 0.21 & 0.16 & 0.22 & 0.37 & 0.16 & 0.09 & 0.32 \\
\hline $\mathrm{K}_{2} \mathrm{O}$ & 0.02 & 0.03 & 0.02 & 0.14 & 0.08 & 0.02 & 0.02 & 0.07 \\
\hline $\mathrm{P}_{2} \mathrm{O}_{5}$ & 0.00 & 0.00 & 0.00 & 0.00 & 0.01 & 0.01 & 0.02 & 0.01 \\
\hline $\mathrm{Cr}_{2} \mathrm{O}_{3}$ & 40.45 & 29.58 & 35.13 & 21.04 & 32.61 & 50.35 & 18.32 & 32.34 \\
\hline \multirow[t]{2}{*}{ LOI } & -0.3 & 6.02 & 0.3 & 3.9 & -0.9 & -0.25 & 6.05 & -1.11 \\
\hline & 98.06 & 98.46 & 99.01 & 97.34 & 99.77 & 97.65 & 99.90 & 98.93 \\
\hline \multicolumn{9}{|c|}{ Trace-elements (ppm) } \\
\hline Co & 169 & 132 & 214 & 176 & 103 & 120 & 128 & 136 \\
\hline $\mathrm{Cu}$ & 29 & 27 & 37 & 49 & 23 & 36 & 26 & 21 \\
\hline $\mathrm{Ni}$ & 1597 & 1295 & 847 & 1188 & 1334 & 833 & 2237 & 969 \\
\hline $\mathrm{Zn}$ & 1372 & 3207 & 2780 & 2919 & 556 & 2615 & 1115 & 1969 \\
\hline V & 439 & 772 & 648 & 555 & 987 & 342 & 391 & 940 \\
\hline \multicolumn{9}{|c|}{$P G E(p p b)$} \\
\hline $\mathrm{Ir}$ & 42 & 241 & & & 75 & 63 & 28 & 10 \\
\hline $\mathrm{Ru}$ & 329 & 583 & & & 242 & 709 & 355 & 45 \\
\hline $\mathrm{Rh}$ & 8 & 442 & & & 97 & 37 & 20 & 6 \\
\hline $\mathrm{Pt}$ & 6 & 783 & & & 1700 & 42 & 22 & 21 \\
\hline Pd & 1 & 463 & & & 418 & 6 & 10 & \\
\hline
\end{tabular}

2012). The positive correlation between $\mathrm{Cu}$ and Ru contents in chromitites and the absence of correlation between PGE and $\mathrm{Cr}$ or Si (Table 3) contents suggest that the PGE (and especially IPGE) have been entrapped by sulphide phases that now form inclusions within chromite grains. The igneous PGE mineralization most probably originated through separation of a sulphide fraction from the silicate melt, in agreement with the more compatible behaviour of IPGE relative to PPGE in sulphide melts compared to silicate magmas (Sattari et al., 2002). The sulphide melt/silicate magma immiscibility event could have been triggered either by mixing between evolved and primitive magmas (Irvine, 1977) or by assimilation of enclosing gabbros by the fractionating melt (Bédard and Hébert, 1998; Gervilla et al., 2005). Considering the strong metamorphic imprint on the GAC, more detailed geochemical and isotopic analyses are needed to choose between these two processes.The layered chromitite (MA 425) associated with anorthosite-leuco-amphibolite samples also shows a PGE pattern with a peak in Ru but with lower bulk PGE contents and lower Ru/Rh ratio compared to MA 226-400-422. This depletion in bulk PGE and in Ru relative to other PGE could be explained by strong depletion of Ru and, to a lesser extent, bulk PGE contents in the parental melt. Indeed, on the basis of simulations with MELTS and according to mineral compositions, it is stressed that the chromitite in anorthosite has crystallized from evolved aluminous melts in comparison to more primitive Mg-rich and Al-poor chromitites. Hence, the parental melt to evolved chromites was already depleted in PGE, especially IPGE over PPGE, due to the igneous segregation of laurite with more primitive chromites.

(ii) The second phase of mineralization is evidenced by the overgrowth of anhedral irarsite-hollingworthite grains on laurite or as isolated grains within chromite (Fig. 14). This event of sulpho-arsenide crystallization is not marked in bulk PGE patterns as it remobilizes the PGE in a closed system but it is linked to an increase in arsenic activity. A few irarsite and hollingworthite were observed along with rutile and anorthite (Fig. 14c), an igneous or late-magmatic origin is more plausible. (iii) The third mineralizing phase consists of the crystallization of sperrylite in the ferritchromit rim of chromite grains and scarce rustenburgite overgrowth at the rim of laurite. A preferential incorporation of PPGE is observed from both mineralogy and bulk PGE patterns of samples MA 238 and 273 (Fig. 15) which are characterized by higher Rh, Pt and Pd contents (up to $1700 \mathrm{ppb} \mathrm{Pt}$ ). The evolution from IPGE to nearly flat PGM pattern due to PPGE enrichment (Fig. 15) is similar to that observed in Paleoproterozoic ferropicrites from Pechenga (Brügmann et al., 2000). Since ferritchromit preferentially develops around inclusions of chlorite and along the border of chromite grains, this phase of Pt-Pd mineralizations is interpreted as a result of hydrothermal activity under high arsenic activities. Similar conclusions have been drawn for Pt-Pd mineralization in hydrothermally altered ophiolitic chromitites (Leblanc, 1991; Prichard et al., 2008) and for the evolution of the PGM from sulphides, to sulphoarsenides and arsenides followed by hydrothermal intermetallic alloys that are also observed in the Two Duck lake intrusion from the Coldwell complex (Watkinson and Ohnenstetter, 1992).

\subsection{The Guelb el Azib complex: the metamorphosed equivalent of Archean anorthosite layered bodies}

The GAC shares many similarities with Archean anorthosite complexes. It is occurring within TTG terrains in close spatial association with suprecrustals (impure marbles, amphibolites, BIF), it is characterized by highly calcic anorthosite and Fe-rich chromite and it is structured as layered sequences of olivine-rich cumulate rocks, former gabbros and anorthosites with minor pyroxenites and few hornblendites bodies (see Windley and Garde, 2009; Rollinson et al., 2010; Polat et al., 2011, 2012).

It is difficult to ascribe a tectonic setting to the GAC due to strong recrystallization under granulite to greenschist facies conditions. But several lines of evidences point to a subduction zone origin:

(i) The highly calcic composition of plagioclase in anorthosites and the hydrous nature of the primitive melts are characteristic of modern hydrous arc magmas and xenoliths (Arculus and 
Wills, 1980; Takagi et al., 2005). (ii) As pointed out by Rollinson et al. (2010), the association amphibole-calcic plagioclase-ferrian chromites is also found in arc xenoliths (Arculus and Wills, 1980), even if the primary or secondary origin of amphibole is debated in layered anorthosite complexes (Owens and Dymek, 1997; Rollinson et al., 2010; Dutta et al., 2011; this study). (iii) The interpretation of spinel compositions in terms of tectonic setting is not straightforward. Indeed, compositional fields of chromites from various modern Phanerozoic tectonic settings are largely overlapping (Barnes and Roeder, 2001) and most GAC chromites plot in the fields of modern flood basalts in the Fe\#-Cr\# plot but falls in the ophiolite field in the trivalent ion plot. Rollinson et al. (2010) moreover noticed that some spinels in modern arc tholeiites have composition close to those analysed in UMA complexes.

The $\mathrm{FeO} / \mathrm{MgO}$ ratio and $\mathrm{Al}_{2} \mathrm{O}_{3}$ content of the melts in equilibrium with igneous chromites are very comparable to modern continental (Cascades) and oceanic (Izu-Bonin) arc basalts (Fig. 16, comparison data from the online GEOROC database).

The GAC chromites with preserved igneous compositions are comparable to those analysed in the Archean Fiskenaesset and Sittampundi UMA complexes (Figs. 7b and 8). A supra-subduction zone origin is proposed by Polat et al. (2009, 2010, 2011, 2012) for the Fiskenaesset complex on the basis of trace-element and isotopic data (negative $\mathrm{Nb}$ anomalies in most samples, positive initial $\varepsilon$ $\mathrm{Nd}$ ). Although the few petrological evidences converge to a suprasubduction zone setting for the GAC, more detailed geochemical analysis are needed to confirm this hypothesis.

\section{Conclusions}

The Archean Guelb el Azib complex in the West African craton is a metamorphosed equivalent of famous Archean anorthosite bodies. Despite granulite (up to $900{ }^{\circ} \mathrm{C}, 5 \mathrm{kbar}$ ) to greenschist metamorphic events that have affected the complex, few preserved igneous mineral compositions and the lithological nature of the igneous precursors before metamorphism lead to the following conclusions:

- The primitive melt was a slightly hydrous high alumina basaltic melt. It evolved towards Archean tholeiite-like composition through the massive fractionation of olivine and chromite generating a sequence of ultramafic cumulates now transformed into serpentinites and olivine-amphibole-spinel rocks (metatroctolites).

- Fe-rich, Cr-poor chromites, An-rich anorthosite and metamorphosed gabbros formed from an Archean tholeiite parental melt. The wide crystallization window of chromite and the calcic nature of the plagioclase are promoted by the lack of massive fractionation of clinopyroxene.

- IPGE minerals such as laurite were precipitated during igneous crystallization of chromitites and IPGE were remobilized during late-magmatic crystallization of hollingworthite and irarsite. A Pt-Pd phase of mineralization, represented by sperrylite and rustenburgite is linked with late low-temperature hydrothermal metamorphism.

- The main petrological characteristics of the GAC are compatible with low-pressure of crystallization at depth corresponding to upper or middle crust. Geochemical analyses are needed to precise the tectonic setting of the GAC but, by comparison with other Archean anorthosite complexes, it could have been formed in a supra-subduction zone setting.

\section{Acknowledgements}

This study was funded by a FRS-FNRS grant to JB. We would like to thank Mohamed Dahmada, Ousmane N'Diaye (deceased in
November 2010), Maloum Baba, Med Salem and the OMRG for their support and for the fantastic fieldtrip in the Amsaga during November 2008. Reviews made by Hugh Rollinson and an anonymous referee together with the editorial handling of Guochun Zhao were greatly appreciated.

\section{References}

Arculus, R.J., Wills, K.J.A., 1980. The petrology of plutonic blocks and inclusions from the lesser antilles island arc. Journal of Petrology 21, 743-799.

Alonso-Perez, R., Müntener, O., Ulmer, P., 2009. Igneous garnet and amphibole fractionation in the roots of island arcs: experimental constraints on andesitic liquids. Contributions to Mineralogy and Petrology 157, 541-558.

Ashwal, L.D., 1993. Anorthosites. Springer-Verlag, Berlin, 422pp.

Augé, T., 1985. Platinum group mineral inclusions in ophiolitic chromites from the Vourinos complex, Greece. The Canadian Mineralogist 23, 163-171.

Auvray, B., Peucat, J.J., Potrel, A., Burg, J.P., Caruba, C., Lo, K., 1992. Données géochronologiques nouvelles sur 1'Archéen de 1'Amsaga (Dorsale Réguibat, Mauritanie). Comptes Rendues de 1'Académie dés Sciences de Paris 315, 63-70.

Barnes, S.J., Roeder, P.L., 2001. The range of spinel compositions in terrestrial mafic and ultramafic rocks. Journal of Petrology 42, 2279-2302.

Barrère, J., 1967. Le groupe précambrien de l'Amsaga entre Afar et Akjoujt (Mauritanie). Etude d'un métamorphisme profond et de ses relations avec la migmatisation. Unpublished PhD Thesis, Clermont-Ferrand, France, 275pp.

Barton, J.M., 1996. The messina layered intrusion, Limpopo Belt, South Africa: an example of in-situ contamination of an Archean anorthosite complex by continental crust. Precambrian Research 78, 139-150.

Bédard, J.H., Hébert, R., 1998. Formation of chromitites by assimilation of crustal pyroxenites and gabbros into peridotitic intrusions: North Arm Mountain massif, Bay of Islands ophiolite, Newfoundland, Canada. Journal of Geophysical Research 103, 5165-5184.

Berger, J., Féménias, O., Ohnenstetter, D., Plissart, G., Mercier, J.C.C., 2010. Origin and tectonic significance of corundum-kyanite-sapphirine amphibolites from the Variscan French Massif Central. Journal of Metamorphic Geology 28, 341-360.

Berndt, J., Koepke, J., Holtz, F., 2005. An experimental investigation of the influence of water and oxygen fugacity on differentiation of MORB at $200 \mathrm{MPa}$. Journal of Petrology 46, 135-167.

Brenan, J.M., Andrews, D., 2001. High-temperature stability of laurite and Ru-Os-Ir alloy and their role in PGE fractionation in mafic magmas. The Canadian Mineralogist 39, 341-360.

Brenan, J.M., Finnigan, C.F., McDonough, W.F., Homolova, V., 2012. Experimental constraints on the partitioning of Ru, Rh, Ir, Pt and Pd between chromite and silicate melt: the importance of ferric iron. Chemical Geology 302-303, 16-32.

Brügmann, G.E., Hanski, E.J., Naldrett, A.J., Smolkin, V.F., 2000. Sulphide segregation in ferropicrites from the Pechenga Complex, Kola Peninsula, Russia. Journal of Petrology 41, 1721-1742.

Cabri, L.J., 2002. The geology, geochemistry, mineralogy and mineral beneficiation of platinum-group elements. CIM Special Volume 54, 852

Connolly, J.A.D., 2005. Computation of phase equilibria by linear programming: a tool for geodynamic modeling and its application to subduction zone decarbonation. Earth and Planetary Science Letters 236, 524-541.

Dharma Rao, C.V., Santosh, M., Sajeev, K., Windley, B.F. Chromite-silicate chemistry of the Neoarchean Sittampundi Complex, southern India: implications for subduction-related arc magmatism. Precambrian Research, http://dx.doi.org/10.1016/j.precamres.2011.11.012, in press.

Diener, J.F.A., Powell, R., White, R.W., Holland, T.J.B., 2007. A new thermodynamic model for clino- and orthoamphiboles in the system $\mathrm{Na}_{2} \mathrm{O}-\mathrm{CaO}-\mathrm{FeO}-\mathrm{MgO}-\mathrm{Al}_{2} \mathrm{O}_{3}-\mathrm{SiO}_{2}-\mathrm{H}_{2} \mathrm{O}-\mathrm{O}$. Journal of Metamorphic Geology $25,631-656$

Dutta, U., Bhui, U.K., Sengupta, P., Sanyal, S., Mukhopadhyay, D., 2011. Magmatic and meta-morphic imprints in $2.9 \mathrm{Ga}$ chromitites from the Sittampundi layered complex, Tamil Nadu, India. Ore Geology Reviews 40, 90-107.

Feig, S., Koepke, J., Snow, J., 2006. Effect of water on tholeiitic basalt phase equilibria: an experimental study under oxidizing conditions. Contributions to Mineralogy and Petrology 152, 611-638.

GEOROC online database. http://georoc.mpch-mainz.gwdg.de/georoc/

Gervilla, F., Proenza, J.A., Frei, R., González-Jiménez, J.M., Garrido, C.J., Melgarejo, J.C., Meibom, A., Díaz-Martínez, R., Lavaut, W., 2005. Distribution of platinum-group elements and Os isotopes in chromite ores from Mayarí-Baracoa Ophiolitic Belt (eastern Cuba). Contributions to Mineralogy and Petrology 150, 589-607.

Giuliani, G., Fallick, A., Rakotondrazafy, M., Ohnenstetter, D., Andriamamonjy, A., Ralantoarison, T., Rakotosamizanany, S., Razanatseheno, M., Offant, Y., Garnier, V., Dunaigre, C., Schwarz, D., Mercier, A., Ratrimo, V., Ralison, B., 2007. Oxygen isotope systematics of gem corundum deposits in Madagascar: relevance for their geological origin. Mineralium Deposita 42, 251-270.

Grove, T.L., Baker, M.B., 1984. Phase equilibrium controls on the tholeiitic versus calcalkaline differentiation trends. Journal of Geophysical Research 89, 3253-3274.

Hamada, M., Fujii, T., 2008. Experimental constraints on the effects of pressure and $\mathrm{H}_{2} \mathrm{O}$ on the fractional crystallization of high-Mg island arc basalt. Contributions to Mineralogy and Petrology 155, 767-790.

Henderson, P., Fishlock, S.J., Laul, J.C., Cooper, T.D., Conard, R.L., Boynton, W.V., Schmitt, R.A., 1976. Rare earth element abundances in rocks and minerals from the Fiskenaesset Complex, West Greenland. Earth and Planetary Science Letters 30, 37-49. 
Hoatson, D.M., Sun, S.-S., 2002. Archean layered mafic-ultramafic intrusions in the West Pilbara Craton, Western Australia: a synthesis of some of the oldest orthomagmatic mineralizing systems in the world. Economic Geology 97, 847-872.

Hoffmann, J.E., Münker, C., Næraa, T., Rosing, M.T., Herwartz, D., Garbe-Schönberg, D. Svahnberg, H., 2011. Mechanisms of Archean crust formation by high precision HFSE systematics on TTGs. Geochimica et Cosmochimica Acta 75, 4157-4178.

Hoffmann, J.E., Svahnberg, H., Piazolo, S., Scherstén, A., Münker, C., 2012. The geodynamic evolution of Mesoarchean anorthosite complexes inferred from the Naajat Kuuat Complex, southern West Greenland. Precambrian Research 196-197, 149-170.

Holland, T., Blundy, J., 1994. Nonideal Interactions in calcic amphiboles and their bearing on amphibole-plagioclase thermometry. Contributions to Mineralogy and Petrology 116, 433-447.

Holland, T.J.B., Powell, R., 1996. Thermodynamics of order-disorder in minerals 2: symmetric formalism applied to solid solutions. American Mineralogist 81 $1425-1437$.

Holland, T.J.B., Powell, R., 1998. An internally consistent thermodynamic data set for phases of petrological interest. Journal of Metamorphic Geology 16, 309-343.

Holland, T.J.B., Powell, R., 2003. Activity-composition relations for phases in petrological calculations: an asymmetric multicomponent formulation. Contributions to Mineralogy and Petrology 145, 492-501.

Hor, A.K., Hutt, D.K., Smith, J.V., Wakefield, J., Windley, B.F., 1975. Petrochemistry and mineralogy of early Precambrian anorthositic rocks of the Limpopo belt southern Africa. Lithos 8, 297-310.

Irvine, T.N., 1977. Origin of chromite layers in the Muskox intrusion and other stratiform intrusions: a new interpretation. Geology 5, 273-277.

Kamenetsky, V.S., Crawford, A.J., Meffre, S., 2001. Factors controlling chemistry of magmatic spinel: an empirical study of associated olivine, $\mathrm{Cr}$-spinel and melt inclusions from primitive rocks. Journal of Petrology 42, 655-671.

Key, R.M., Loughlin, S.C., Gillespie, M., Del Rio, M., Horstwood, M.S.A., Crowley, Q.G. Darbyshire, D.P.F., Pitfield, P.E.J., Henney, P.J., 2008. Two Mesoarchaean terranes in the Reguibat shield of NW Mauritania. Geological Society of London, Special Publications 297, 33-52.

Leake, B.E., Woolley, A.R., Arps, C.E.S., Birch, W.D., Gilbert, M.C., Grice, J.D. Hawthorne, F.C., Kato, A., Kisch, H.J., Krivovichev, V.G., Linthout, K., Laird, J., Mandarino, J., 1997. Nomenclature of amphiboles: Report of the Subcommittee on Amphiboles of the International Mineralogical Association Commission on New Minerals and Mineral Names. Mineralogical Magazine 61, 295-321.

Leblanc, M., 1991. Platinum-group elements and gold in ophiolitic complexes: distribution and fractionation from mantle to oceanic floor. In: Tj Peters, et al.(Eds.), Ophiolite Genesis and Evolution of the Oceanic Lithosphere, Oman. Kluwer, Dordrecht, pp. 231-260.

Martin, H., Smithies, R.H., Rapp, R., Moyen, J.F., Champion, D., 2005. An overview of adakite, tonalite-trondhjemite-granodiorite (TTG), and sanukitoid: relationships and some implications for crustal evolution. Lithos 79, 1-24.

Maurel, C., Maurel, P., 1983. Étude expérimentale de l.équilibre $\mathrm{Fe}^{2+}-\mathrm{Fe}^{3+}$ dans les spinelles chromifères et les liquides silicatés basiques coexistants, à $1 \mathrm{~atm}$. Comptes Rendus de l'Académie des Sciences 295, 209-212.

Mouri, H., Whitehouse, M.J., Brandl, G., Rajesh, H.M., 2009. A magmatic age and four successive metamorphic events recorded in zircons from a single metaanorthosite sample in the Central Zone of the Limpopo Belt, South Africa. Journal of the Geological Society 166, 827-830.

Mukherjee, R., Mondal, S., Rosing, M., Frei, R., 2010. Compositional variations in the Mesoarchean chromites of the Nuggihalli schist belt, Western Dharwar Craton (India): potential parental melts and implications for tectonic setting. Contributions to Mineralogy and Petrology 160, 865-885.

Muntener, O., Kelemen, P.B., Grove, T.L., 2001. The role of $\mathrm{H}_{2} \mathrm{O}$ during crystallization of primitive arc magmas under uppermost mantle conditions and genesis of igneous pyroxenites: an experimental study. Contributions to Mineralogy and Petrology 141, 643-658.

Myers, J.S., 1976. Channel deposits of peridotite, gabbro and chromitite from turbidity currents in the stratiform Fiskenæsset anorthosite complex, southwest Greenland. Lithos 9, 281-291.

Naldrett, A.J., Duke, J.M., 1980. Platinum metals in magmatic sulfide ores. Science 208, 1417-1428.

Naldrett, A., Wilson, A., Kinnaird, J., Yudovskaya, M., Chunnett, G., 2012. The origin of chromitites and related PGE mineralization in the Bushveld Complex: new mineralogical and petrological constraints. Mineralium Deposita 47, 209-232.

Owens, B.E., Dymek, R.F., 1997. Comparative petrology of Archaean anorthosites in amphibolite and granulite facies terranes, SW Greenland. Contributions to Mineralogy and Petrology 128, 371-384.

Ozawa, K., 1983. Evaluation of olivine-spinel geothermometry as an indicator of thermal history for peridotites. Contributions to Mineralogy and Petrology 82 52-65.
Pagé, P., Barnes, S.-J., Bédard, J.H., Zientek, M.L., 2012. In situ determination of Os, Ir, and Ru in chromites formed from komatiite, tholeiite and boninite magmas: implications for chromite control of Os, Ir and Ru during partial melting and crystal fractionation. Chemical Geology 302-303, 3-15.

Phinney, W.C., Morrison, D.A., Maczuga, D.E., 1988. Anorthosites and related megacrystic units in the evolution of Archean crust. Journal of Petrology 29, 1283-1323.

Polat, A., Appel, P.W.U., Fryer, B., Windley, B., Frei, R., Samson, I.M., Huang, H., 2009. Trace element systematics of the Neoarchean Fiskenæsset anorthosite complex and associated meta-volcanic rocks, SW Greenland: evidence for a magmatic arc origin. Precambrian Research 175, 87-115.

Polat, A., Frei, R., Scherstén, A., Appel, P.W.U., 2010. New age (2970 Ma), mantle sources and geodynamic constraints on the Archean Fiskenæsset anorthosite complex. Chemical Geology 277, 1-20.

Polat, A., Fryer, B., Appel, P.W.U., Kalvig, P., Kerrich, R., Dilek, Y., Yang, Z., 2011. Geochemistry of anorthositic differentiated sills in the Archean ( 2970 Ma) Fiskenæsset Complex, SW Greenland: implications for parental magma compositions, geodynamic setting, and secular heat flow in arcs. Lithos 123, 50-72.

Polat, A., Fryer, B.J., Samson, I.M., Weisener, C., Appel, P.W.U., Frei, R., Windley, B.F. 2012. Geochemistry of ultramafic rocks and hornblendite veins in the Fiskenæsset layered anorthosite complex, SW Greenland: evidence for hydrous upper mantle in the Archean. Precambrian Research 214-215, 124-153.

Potrel, A., 1994. Evolution tectono-métamorphique d'un segment de croüte continentale archéenne. Exemple de 1'Amsaga (R.I. Mauritanie), Dorsale Réguibat (craton Quest Africain). Unpublished PhD Thesis, Rennes, France, 400pp.

Potrel, A., Peucat, J.J., Fanning, C.M., Auvray, B., Burg, J.P., Caruba, C., 1996. 3.5 Ga old terranes in the West African Craton, Mauritania. Journal of the Geological Society 153, 507-510.

Potrel, A., Peucat, J.J., Fanning, C.M., 1998. Archean crustal evolution of the west African craton: example of the Amsaga area (Reguibat rise). $\mathrm{U}-\mathrm{Pb}$ and $\mathrm{Sm}-\mathrm{Nd}$ evidence for crustal growth and recycling. Precambrian Research 90 107-117.

Prichard, H.M., Neary, C.R., Fisher, P.C., O'Hara, M.J., 2008. PGE-rich podiform chromitites in the Al'Ays Ophiolite Complex, Saudi Arabia: an example of critical mantle melting to extract and concentrate PGE. Economic Geology 103, 1507-1529.

Raith, M.M., Rakotondrazafy, R., Sengupta, P., 2008. Petrology of corundum-spinel-sapphirine-anorthite rocks (sakenites) from the type locality in southern Madagascar. Journal of Metamorphic Geology 26, 647-667.

Rollinson, H.R., Appel, P.W.U., Frei, R., 2002. A metamorphosed, early Archaean chromitite from west Greenland: implications for the genesis of Archaean anorthositic chromitites. Journal of Petrology 43, 2143-2170.

Rollinson, H., Reid, C., Windley, B., 2010. Chromitites from the Fiskenæsset anorthositic complex, West Greenland: clues to late Archaean mantle processes. Geological Society of London, Special Publications 338, 197-212.

Sattari, P., Brenan, J.M., Horn, I., McDonough, W.F., 2002. Experimental constraint on the sulfide- and chromite-silicate melt partitioning behavior of rhenium and platinum-group elements. Economic Geology 97, 385-398.

Sisson, T.W., Grove, T.L., 1993. Experimental investigations of the role of $\mathrm{H}_{2} \mathrm{O}$ in calcalkaline differentiation and subduction zone magmatism. Contributions to Mineralogy and Petrology 113, 143-166.

Takagi, D., Sato, H., Nakagawa, M., 2005. Experimental study of a low-alkali tholeiite at 1-5 kbar: optimal condition for the crystallization of high-An plagioclase in hydrous arc tholeiite. Contributions to Mineralogy and Petrology 149, 527-540.

Tenthorey, E.A., Ryan, J.G., Snow, E.A., 1996. Petrogenesis of sapphirine-bearing metatroctolites from the Buck Creek ultramafic body, southern Appalachians. Journal of Metamorphic Geology 14, 103-114.

Villiger, S., Ulmer, P., Muntener, O., Thompson, A.B., 2004. The liquid line of descent of anhydrous, mantle-derived, tholeiitic liquids by fractional and equilibrium crystallization - an experimental study at 1 center dot 0 GPa. Journal of Petrology 45, 2369-2388.

Villiger, S., Ulmer, P., Muntener, O. 2007. Equilibrium and fractional crystallization experiments at $0.7 \mathrm{GPa}$; the effect of pressure on phase relations and liquid compositions of tholeiitic magmas. Journal of Petrology 48, 159-184.

Watkinson, D.H., Ohnenstetter, D., 1992. Hydrothermal origin of platinum-group mineralization in the Two Duck Lake intrusion, Coldwell Complex, northwestern Ontario. Canadian Mineralogist 30, 121-136.

Weaver, B.L., Tarney, J., Windley, B., 1981. Geochemistry and petrogenesis of the Fiskenaesset anorthosite complex, southern West Greenland: nature of the parent magma. Geochimica Et Cosmochimica Acta 45, 711-725.

Windley, B.F., Bishop, F.C., Smith, J.S., 1981. Metamorphosed layered igneous complexes in Archean Granulite-Gneiss Belts. Annual Reviews in Earth Planetary Science 9, 175-198.

Windley, B.F., Garde, A.A., 2009. Arc-generated blocks with crustal sections in the North Atlantic craton of West Greenland: crustal growth in the Archean with modern analogues. Earth Science Reviews 93, 1-30. 